

\section{Geology of the Arabian Peninsula Jordan}

By FRIEDRICH BENDER

GEOLOGICAL SURVEY PROFESIONAL PAPER 560-I

Prepared in cooperation with the

Government of Jordan and the

Geological Survey of the

Federal Republic of Germany

A review of the geology of Jordan, a supplement

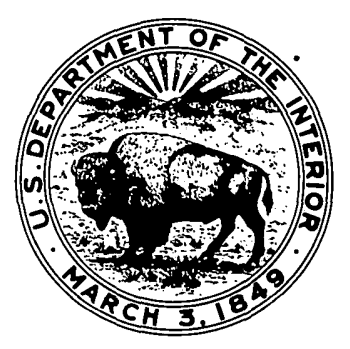

to USGS Miscellaneous Geologic Investigations.

Map I-270-A, "Geologic map of the Arabian

Peninsula," 1963 


\section{UNITED STATES DEPARTMENT OF THE INTERIOR \\ STANLEY K. HATHAWAY, Secretary}

\section{GEOLOGICAL SURVEY}

V. E. McKelvey, Director

Library of Congress Cataloging in Publication Data (Revised)

Main entry under title:

Geology of the Arabian Peninsula.

(Geological Survey professional paper 560)

Part of illustrative matter in pocket.

Includes bibliographies.

CONTENTS: B. Yemen, by. F. Geukens.-C. Aden Protectorate, by J. E. G. W. Greenwood and D. Bleackley. -D. Sedimentary geology of Saudi Arabia, by R. W. Powers and others. [etc.] Supt. of Docs. no.: I 19.16:560-I

1. Geology-Arabia. 2. Geology-Near East. I. Series: U. S. Geological Survey. Professional paper 560. QE75.P9 no. $560 \quad 555.3 \quad 70-604863$

For sale by the Superintendent of Documents, U.S. Government Printing Office

Washington, D.C. 20402

Stock Number 2401-02547 


\section{FOREWORD}

This volume, "The Geology of the Arabian Peninsula," is a logical consequence of the geographic and geologic mapping project of the Arabian Peninsula, a cooperative venture between the Kingdom of Saudi Arabia and the Government of the United States. The ArabianAmerican Oil Co. and the U.S. Geological Survey did the fieldwork within the Kingdom of Saudi Arabia, and, with the approval of the governments of neighboring countries, a number of other oil companies contributed additional mapping to complete the coverage of the whole of the Arabian Peninsula. So far as we are aware, this is a unique experiment in geological cooperation among several governments, petroleum companies, and individuals.

The plan for a cooperative mapping project was originally conceived in July 1953 by the late William E. Wrather, then Director of the U.S. Geological Survey, the late James Terry Duce, then Vice President of Aramco, and the late E. L. deGolyer. George Wadsworth, then U.S. Ambassador to Saudi Arabia, and Sheikh Abdullah Sulaiman, then Minister of Finance of the Government of Saudi Arabia, lent their support to the plan. In November of the following year, 1954, Director Wrather approved the U.S. Geological Survey's participation and designated G. F. Brown responsible for the western Arabian shield region in which he had previously worked under U.S. foreign-aid programs. In January 1955 F. A. Davies, Chairman, Board of Directors, Arabian-American Oil Co., approved Aramco's participation and appointed the late R. A. Bramkamp, chief geologist, responsible for compilation of the area within the Kingdom where the sediments crop out. This responsibility fell to L. F. Ramirez following the death of R. A. Bramkamp in September 1958.

R. A. Bramkamp and G. F. Brown met in New York in February 1955 and planned the program, including scales of maps, areas of responsibility, types of terrain representation, and bilingual names. Thus there was established a cooperative agreement between the Kingdom of Saudi Arabia, the U.S. Department of State, and the Arabian-American Oil Co. to make available the basic areal geology as mapped by Aramco and the U.S. Geological Survey.

The agreement specified publication of a series of 21 maps on a scale of 1:500,000, each map covering an area $3^{\circ}$ of longitude and $4^{\circ}$ of latitude. Separate geologic and geographic versions were to be printed for each of the quadrangles; both versions were to be bilingual-in Arabic and English. A peninsular geologic map on a scale of 1:2,000,000 was to conclude the project.

High-altitude photography, on a scale of 1:60,000, of the Kingdom of Saudi Arabia was initiated during 1949 by the Aero Service Corp. and completed in 1959. Both third-order vertical and horizontal control and shoran were utilized in compiling the photography. This controlled photography resulted in highly accurate geographic maps at the publication scale which then served as a base for the geologic overlay. The topography of the sedimentary areas was depicted by hachuring and that of the shield region by shaded relief utilizing the airbrush technique.

The first geographic quadrangle was published in July 1956 and the last in September 1962. While preparation of the geographic sheets was in progress, a need arose for early publication of a 1:2,000,000-scale peninsular geographic map. Consequently, a preliminary edition was compiled and published in both English and Arabic in 1958. The second edition, containing additional photography and considerable new topographic and cultural data, was published in 1963. The first of the geologic map series was published in July 1956 and the final sheet in early 1964. The cooperative map project was completed in October 1963 with 
the publication of the 1:2,000,000-scale "Geologic Map of the Arabian Peninsula" (Miscellaneous Geologic Investigations Map I-270-A).

As work on the quadrangles progressed, geologists, companies, and governments working in areas adjacent to the Kingdom of Saudi Arabia were consulted by Aramco and invited to participate in the mapping project. The number of cooperating participants was expanded to 11 , which included the operating oil companies in the peninsula and which are identified elsewhere in this text; the Overseas Geological Surveys, London; the Government of Jordan; F. Geukens, who had worked in Yemen; and Z. R. Beydoun, who had studied the Eastern Aden Protectorate. With the close cooperation of the authors, the new data were added to data already plotted on the base map of the Arabian Peninsula.

As the geological coverage of the peninsular map grew, the need for a text to accompany the map became apparent to both the U.S. Geological Survey and the Aramco geologists. Exploratory conversations were begun by Aramco with companies working in the other countries of the Arabian Peninsula for their participation in the preparation of a monograph on the geology of the Arabian Peninsula. Each author prepared a description of the geology of the area for which he was responsible, as shown in the sources of geologic compilation diagram on the peninsular map. The U.S. Geological Survey undertook the publishing of the volume as a professional paper, and the Government of Saudi Arabia was to finance its printing. It was early agreed that there would be no effort to confine the contributions to a standard format and that no attempt would be made to work out an overall correlation chart other than shown on the "Geologic Map of the Arabian Peninsula." Thus, the individual style of authors of several nationalities is preserved.

Cooperation and relations have been of the highest order in all phases of the work. The project would not have been possible without the full support of the U.S. Department of State, the Kingdom of Saudi Arabia, and all contributors. In fact, the funds which made publication of this volume possible were contributed by the Saudi Arabian Government.

The data provided by the maps and in the professional paper provide information for an orderly scientific and economic development of a subcontinent.

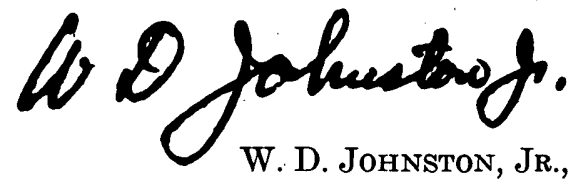

Former Chief, Foreign Geology Branch, U.S. Geological Survey.

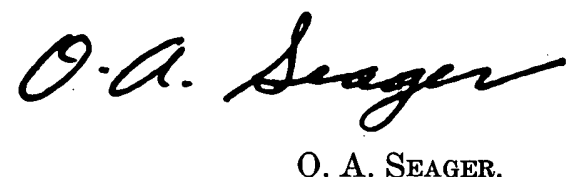

Arabian-American Oil Co. (Retired).

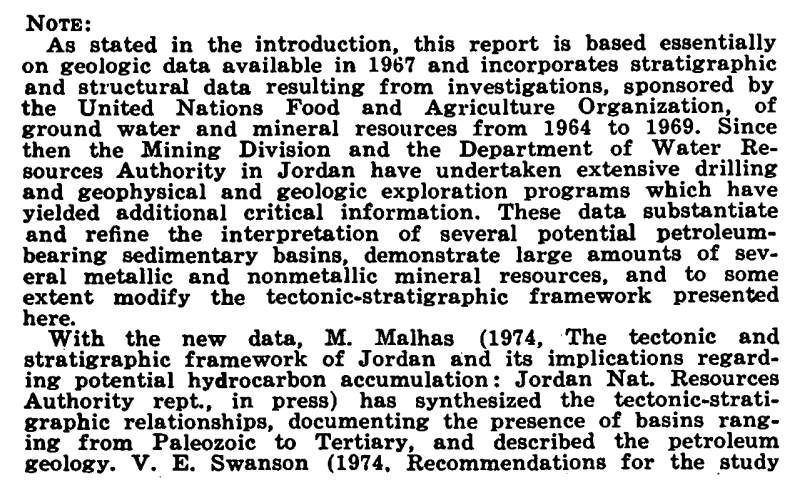

Note:

As stated in the introduction, this report is based essentially and structural data resulting from investigations, sponsored by United Nations Food and Agriculture Organization, of then the Mining Division and the Department of Water Reand suthority in Jordan have undertaken extensive which have ielded additional critical information. These data substantiate bearing sedimentary basins, demonstrate large amounts of sev-

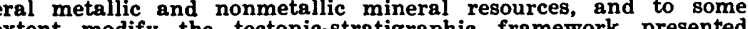
here. and graphic relationships, doumenting the presence of basins ranggeology. V. E. Swanson (1974. Recommendations for the study and appraisal of oil shale deposits in Jordan: U.S. Geol. Survey open-file rept.) evaluated the oil shale resources and development programs of Jordan and concluded that the inferred reserves were very large. Recent work by the Natural Resources Authority (1972, The mineral prospects of Jordan: Jordan Nat. Resources Authority Mining Div., unpub. rept., 22 p.) indicates prospective reserves as large as 10 billion metric tons of shale containing $1 \mathrm{bbl} /$ metric ton $(\mathrm{p} .20)$. Y. F. Nimry (1973, The copper and manganese prospects of Wadi Araba: . the Mining Division of the Natural Resources Authority large resources of copper and manganese have been identified in the vicinity of Faynan on the east side of Wādi al Arabah. Other studies by the Mining Division indicate large resources of several nonmetallic minerals. More recent information on the availability of phosphate, glass sand, clay, tripoli, gypsum, also available from the Natural Resources Authority (1972). Projes are on 


\section{CONTENTS}

Foreword

Abstract -.-

Introduction

Scope of contribution

Previous work -

Acknowledgments -

General geomorphology -............

Geologic history and paleogeography -........--

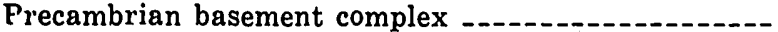

Metamorphic rocks

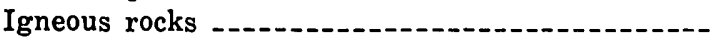

Upper Proterozoic sedimentary rocks -...--

Upper Praterozoic-Paleozoic volcanic and associated rocks

Post-Proterozoic stratigraphy and volcanism --1

Paleozoic Era

Mesozoic volcanic rocks

Cenozoic Era

Cenozoic volcanic rocks

\begin{tabular}{r|} 
Page \\
III \\
I1 \\
1 \\
1 \\
1 \\
3 \\
3 \\
8 \\
12 \\
12 \\
12 \\
13 \\
\\
14 \\
14 \\
14 \\
17 \\
20 \\
20 \\
22
\end{tabular}

Structure

Wādi al 'Arabah-Jordan Rift -...-...-.-- 23

Nubo-Arabian Shield in southern Jordan -..--- 24

Block faults in central and southeastern Jordan-- 25

Upwarping, tilting, and block faulting in

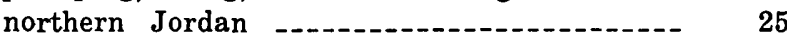

Anticlinorium, upwarping, and block faulting

west of the Jordan River -

Economic geology -.-- 25

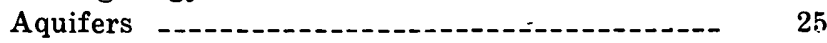

Oil and gas, bituminous rocks, and asphalt ----- 26

Metallic minerals _._.

Copper -...-...- 27

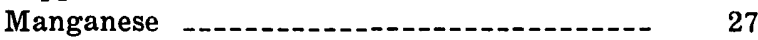

Iron --

Chromium, nickel, uranium, and pyrite -.-- 29

Nonmetallic minerals -...-.-_- 29

Phosphate -

Other minerals -..- 31

Selected references

\section{ILLUSTRATIONS}

[Plates are in pocket]

Plate 1. Geologic map of Jordan.

2. Correlation chart of lithostratigraphic units in Jordan.

3. Structure contour map of the top of the Precambrian rock complex, Jordan.

Figures 1. Index map showing physiographic-geologic provinces in Jordan

Page

1. Index map showing phys
210. Photographs showing:

2. Precambrian granodiorite and dikes and overlying Cambrian sandstone, southern Jordar.

3. Cambrian and Lower Ordovician sandstone, southern Jordan

4. Middle and Upper Ordovician sandstone and shale, southern Jordan -

5. Beginning of flexure in Upper Cretaceous limestone and

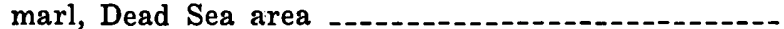

6. Outlier Tuwayyil ash Shihăq, central Jordan

7. Basalt flow cracked by insolation, northeast Jordan ---

8. Aerial view of wadis and mudflats that follow structural pattern, northeast Jordan -

9. The Wādi al 'Arabah-Jordan Rift at its lowest point --

10. Upper Cretaceous rocks, western edge of Wādi al

'Arabah-Jordan Rift

11. Paleogeographic map of Jordan 
Figures 12-15. Photographs showing:

Page

12. Biotite schist in aplite granite

13. Aerial view of mafic, intermediate, and silicic dikes, southern Jordan

14. Angular unconformity between the upper Proterozoic Slate-Graywacke Series and Cambrian sandstone ---

15. Intrusion of quartz porphyry into Cambrian sandstone

16. Composite columnar section of Cretaceous and Paleozoic sedimentary rocks in south Jordan

17. Map showing occurrences and indications of minerals and rocks of economic interest and locations of oil exploration wells in Jordan

18. North-south correlation of Upper Cretaceous-lower Tertiary lithostratigraphic units

19. Photograph showing phosphate in open-pit mine
112 


\section{GEOLOGY OF THE ARABIAN PENINSULA}

\section{JORDAN}

BY FRIEDRICH BENDER ${ }^{1}$

\section{ABSTRACT}

The Hashemite Kingdom of Jordan covers an area of approximately $96,500 \mathrm{~km}^{3}$ in the northwestern part of the Arabian Peninsula.

In southwestern Jordan, part of the Nubo-Arabian Shield is exposed. It is characterized by Precambrian plutonic and metamorphic rocks, and by some minor occurrences of upper Proterozoic sedimentary rocks. Cambrian, Ordovician, and Silurian sandstone and shale of continental and marine origin have a maximum thickness of $1,800 \mathrm{~m}$ and unconformably overlie the rocks of the Precambrian basement complex.

A belt of sedimentary rocks deposited chiefly on the stable shelf area of the Tethys Sea borders the northern fringe of the shield. Most of southeastern and central Jordan is within this belt. It is a zone of interfingering sedimentary rocks of continental, littoral, and neritic origin, rapid lateral facies changes, and many stratigraphic unconformities caused by pulsation and, at certain periods, transgression and regression of the Tethys Sea. Regionally, the marine influence on the deposition increases toward the north and west. The total thickness of all post-Proterozoic sedimentary rocks is $2,000-3,000 \mathrm{~m}$; it exceeds $4,000 \mathrm{~m}$ in the baylike sedimentary basin of $\mathrm{Al} \mathrm{Jafr}$ in south-central Jordan, and 5,000 $\mathrm{m}$ in the Al Azraq-Wādi as Sirhān Basin in north-central Jordan. These basins strike northwest and thus seem to merge with the unstable shelf area of the Tethys Sea in the northwest.

In the transition zone to, and in the area of, the unstable shelf in northwestern, northern, and probably northeastern Jordan, neritic and bathyal sedimentary rocks form the major part of the post-Paleozoic rocks. Here, the stratigraphic sequence is more complete, unconformities are fewer, and lateral facies changes are less pronounced than in the stable shelf area to the south and southeast. In northwestern Jordan, west of the Jordan River, the total thickness of sedimentary rocks above the Precambrian basement may be as much as $7,000 \mathrm{~m}$; in the Dead Sea area of the Wādi al 'Arabah-Jordan Rift province, repeated structural subsidence resulted in the accumulation of sedimentary rocks as much as $10,000 \mathrm{~m}$ thick.

No evidence is known of post-Proterozoic structural movements characteristic of alpine orogenesis. The crustal movements affecting the country since the Cambrian were gentle regional tiltings (epeirogenic movements) and a combination of faulting, block folding, and taphrogenic movements. The

1 Geological Survey of the Federal Republic of Germany. majority of structural features were caused by tensional forces. Evidence of compression is rare and chiefly restricted to west Jordan and to north Jordan east of the Rift.

Major volcanic activity occurred during the late Proterozoic and Early Cambrian (quartz porphyries, Wādī al 'Arabah), during the Late Jurassic(?) and Neocomian (mafic and intermediate eruptive rocks, Wādì al 'Arabah and west of the Jordan River), and during the Neogene (includes Miocene and Pliocene as used in this report) and Pleistocene (extensive basalt volcanism).

\section{INTRODUCTION}

\section{SCOPE OF CONTRIBUTION}

This report describes the geology of that part of the northwestern Arabian Peninsula, the Hashemite Kingdom of Jordan, which was mapped by a geological mission of the Geological Survey of the Federal Republic of Germany, 1961-67. The mapping was done at scales of $1: 25,000,1: 60,000$, and $1: 100,000$ and later compiled at a scale of 1:250,000 (Bender and others, 1968). This map differs in certain areas from Quennell's (1966) geologic map of Jordan east of the Wädi al 'Arabah-Jordan Rift, which covers approximately the western half of Jordan, and which was incorporated in the $1: 2,000,000$-scale geologic map of the Arabian Peninsula (U.S. Geological survey and Arabian-American Oil Company, 1963).

The geographic names in this report conform to the Jordan Gazetteer of 1971, which lists names approved by the U.S. Board on Geographic Names; however, for several names the more popular spelling is given in parentheses both in the report and on plate 1 .

\section{PREVIOUS WORK}

The literature dealing with the geology of Jordan is surprisingly extensive. It has been recently compiled, and an account of the history of geological 
research has been given by Bender (1968a). Therefore, only some significant publications are cited herein.

Seetzen (1810) gave one of the first accounts of a geographic reconnaissance survey; he lost his life on his last expedition (Kruse, 1854-55). In 1837, von Schubert and Roth discovered that the Dead Sea level is considerably lower than the level of the Mediterranean (Hull, 1886, p. 12). Bertou (1839) is reputed to have been the first traveller to travel the length of the Wādi al 'Arabah from the Dead Sea to the Gulf of Aqaba. Russegger (1847) made several expeditions to the "Holy Land" and published a "geognostic" map of Arabia Petraea. Under the leadership of U.S. Navy Lt. Lynch (1852), a survey was undertaken to explore the Dead Sea and the River Jordan. Later, Ritter (1848-55), vom Rath (1881), Fraas (1867a, b), Milne (1875), and Lartet (1876) discussed geologic problems of the Jordan area. The contributions of Hull (1886) incorporated many detailed records on geologic observations and a geologic map of Wādĩ al 'Arabah.

From about 1890 to 1914, Max Blanckenhorn was engaged in geologic research in Palestine and Transjordan. He achieved a comprehensive knowledge of the country and documented his observations in many publications (Blanckenhorn, 1903, 1912, 1914). During that time, the Hejaz Railroad from Damascus (Syria) via 'Ammān. $\mathrm{Ma}$ 'ān, and $\mathrm{Al}$ Mudawwarah to Al Madinah (Saudi Arabia) was planned and constructed. The area thus became more accessible, and geologic research increased considerably (Auler, 1908; Musil, 1907, 1911; Krusch, 1911; Dienemann, 1915; Fuchs, 1916; Kober, 1919; Schwöbel, 1921).

During the period of the British Mandate, King (1923), Cox $(1924,1925,1932,1934)$, Muir-Wood (1925), Wagner (1934), Richter and Richter (1941), and Avnimelech (1945) published reports on the paleontology of Cambrian, Triassic, and Jurassic rocks. Regional geologic problems were discussed by Krenkel $(1924,1925,1941)$ and Hennig (1938). G. S. Blake, as geologist of the British Mandate Government, carried out systematic surveys on mineral and ground-water resources and recorded his findings in many contributions (Blake, 1928, 1930, 1936, 1939; Ionides and Blake, 1939; Blake and Goldschmidt, 1947). Blake lost his life while on a field survey in the Wādi al 'Arabah.

Willis (1928) and Wellings (in Willis, 1938) investigated problems on the evolution of the Jordan Rift. Structural phenomena were also discussed by
Dubertret (1932), who also published geologic maps of the region (Dubertret, 1959, 1962). Since 1928, important contributions to the knowledge of the geology in the Jordan area have been made by Picard (1928, 1931, 1941, 1943, 1953, 1965). Shaw $(1947,1948)$ published a geologic map of southern Palestine and gave an account on the geology and mineral resources of Palestine. A similar contribution was made by Quennell $(1951,1956)$ for the territory of Transjordan. Quennell's maps and geologic findings formed the main basis of Burdon's "Handbook of the geology of Jordan . . ." (1959). A significant contribution, especially on stratigraphic correlation, was published by Wetzel and Morton (1959).

During the last 20 years, geologic consulting that concerned projects for economic development has played an increasing role. Generally, the results are in unpublished reports for the Government of Jordan-for example: Reports of the Transjordan Petroleum Development Co., Ltd. $(1947-49)^{2}$; E. W. Pauley Oil Exploration and Phillips Petroleum Co. $(1956-60)^{3}$; J. W. Mecom Oil Co. $(1964-66)^{4}$; Mackay \& Schnellmann $(1954,1957)^{56}$; Parsons Corp. (1963) ${ }^{7}$; Gold $(1964)^{8}$; Wilson and Wozab (1954) ; Baker and Harza Engineering Co. (1955) ${ }^{9}$; Hunting Technical Services, Ltd. $(1956,1965)^{10}{ }^{11}$; Sir M. Macdonald \& Partners (1965) ${ }^{12}$; Rofe \& Raffety Consultant Engineers $(1963,1965)^{13}{ }^{14}$; the

2 Transjordan Petroleum Development Co., Ltd., 1947-49, Unpub. repts., Jordan Nat. Resources Authority, Amman, Jordan.

${ }^{3}$ E. W. Pauley Oil Exploration and Phillips Petroleum Co., 1956-60, Unpub. repts., Jordan Nat. Resources Authority, Amman, Jordan.

4 J. W. Mecom Oil Co., 1964-66, Unpub. repts., Jordan Nat. Resources Authority, Amman, Jordan.

s Mackay \& Schne!lmann, 1954, Mineral resources in Jordan: London, Mackay, \& Schnellmann Consulting Economic Geologists, unpub. rept.

${ }^{6}$ Mackay \& Schnellmann, 1957. Phosphate resources in Jordan, Roseifa: London, Mackay \& Schnellmann Consulting Economic Geologists, unpub. rept.

${ }^{2}$ Parsons Corporation, 1963, Exploration and geology, v. 2 of El Hasa phosphate project: Los Angeles, Calif., Parsons Corp. Engineering, unpub. rept. 3166-1, Jordan Nat. Resources Authority, Amman, Jordan.

${ }^{8}$ Gold, O., 1964, The Wadi Araba copper exploration, Jordan-report on phase A: Köln, Germany, Ingenieurberatung für Bergbaufragen, unpub. rept. for Jordan Government, Jordan Devel. Board, Amman, Jordan. O Baker, M., and Harza Engineering Co., 1955, Yarmouk-Jordan Valley project, master plan report: Unpub. rept. for the Jordan Government, Jordan Nat. Resources Authority, Amman, Jordan, v. 1-13.

${ }^{10}$ Hunting Technical Services, Ltd., 1956, Range classification survey of the Hashemite Kingdom of Jordan: London, Hunting Tech. Services, Ltd., unpub. rept., Jordan Nat. Resources Authority, Amman, Jordan.

"Hunting Technical Services, Ltd., 1965, Wadi Dhuleil investigation: London, Hunting Tech. Services, Ltd., unpub rept., Jordan Nat. Resources Authority, Amman, Jordan.

${ }^{22}$ Sir M. Macdonald \& Partners, 1965, East bank Jordan water resources, summary report: Sir M. Macdona!d \& Partners, unpub. rept. for the Jordan Government, Jordan Nat. Resources Authority, Amman, Jordan.

${ }^{13}$ Rofe \& Raffety Consultant Engineers, 1963, Jerusalem and district water supp!y, geological and hydrological report: London, Rofe \& Raffety Cons. Engineers, unpub. rept. for Jordan Central Water Authority.

14 Rofe \& Raffety Consultant Engineers, 1965, Nablus district water resources survey: London, Rofe \& Raffety Cons. Engineers, unpub. rept. for Jordan Central Water Authority. 
reports of the United Nations Food and Agriculture Organization (UNFAO) "Sandstone Aquifer Project in southeast-Jordan"; Lloyd (1969); Parker (1969); and the reports of the German Geological Mission (1961-67).

\section{ACKNOWLEDGMENTS}

The author wishes to express his appreciation and thanks to Mr. O. A. Dokhgan, the general director for many years of the Natural Resources Authority of the Hashemite Kingdom of Jordan, who promoted all efforts concerning geologic research in Jordan. The author furthermore greatly appreciates and thanks his colleagues of the German geological mission who shared in the field and office work in Jordan from 1961 to 1967: A. Abdullatif, D. S. Ahmad, G. van den Boom, R. Busse, F. Z. Dajani, A. Futian, J. Grieger, F. Grüneberg, M. Haddadin, W. Heimbach, H. Ibrahim, K. Jeresat, K. M. Khdeir, M. Lahloub, R. Lenz, W. Lillich, M. Nuseibeh, M. Ruef, S. S. Salem, O. Suwwan, B. F. Sunna, Z. Tuqan, and G. Wiesemann.

Special acknowledgment goes to Mr. W. Barber, project manager of the UNFAO "Sandstone Aquifer Project in southeast-Jordan" for many discussions related to the geology of Jordan, and for access to his unpublished material.

Naturally, this paper incorporates results of work by many more geologists who were involved in the collection and processing of data presented here. Each of these contributions is cited individually.

\section{GENERAL GEOMORPHOLOGY}

The Hashemite Kingdom of Jordan covers an area of approximately $96,500 \mathrm{~km}^{2}$ in the northeastern part of the Arabian Peninsula. In contrast to the more uniform and monotonous morphology of most of the interior of the Arabian Peninsula, the western and northwestern parts, including the territory of Jordan, are morphologically distinctive. Jordan may be divided into seven physiographic provinces, which coincide with geologic provinces (fig. 1) :

Southern Mountainous Desert;

Mountain Ridge and Northern Highlands East of the Rift;

Central Plateau (includes Al Jafr and Al AzraqWādì as Sirḩān Basin) ;

Northern Plateau Basalt;

Northeastern Plateau ;

Wādī al 'Arabah-Jordan Rift;

Highlands West of the Rift.
The Southern Mountainous Desert occupies the area south of the west-northwest-striking escarpment of Ra's an Naqb, and extends southward into Saudi Arabia. Between Al 'Aqabah and Al Quwayrah where igneous rocks of the Precambrian basement are exposed, the country is rough, and steep mountains rise to $1,550 \mathrm{~m}$ above sea level (fig. 2). Farther east, Paleozoic and Mesozoic sandstone overlies the Precambrian basement complex, and from Kawr Ramm (Wâdi Ramm) to the east they cover it completely. The sandstones also form steep bizarre cliffs (fig. 3) and mountains more than $1,700 \mathrm{~m}$ in altitude (Jabal Ramm, 1,754 m). Closer to the disused Hejaz Railroad (Al Mudawwarah) and farther east (Jabal at Tubayq), an inselberg landscape of table mountains and large depressions are the dominant topographic features (fig. 4). Broad, generally flat areas near the base level of erosion indicate that the mature stage of the arid erosion cycle has been reached in this region. The debris of arid weathering, drifting sand, and pelitic sediments in extensive mudflats cover the depressions and form very thick fill in erosion channels of the Pleistocene pluvial periods. Drainage in the western part of this physiographic province is to the south into the Gulf of Aqaba and is still actively cutting headward. In the eastern part, drainage turns southeast into the flats south of Al Mudawwarah and east into Wādī as Sirḩān Basin.

The Mountain Ridge and Northern Highlands East of the Rift is a coherent physiographic feature, in spite of its varied geologic character. It stretches north-northeast to north for about $370 \mathrm{~km}$ from the Gulf of Aqaba to Lake Tiberias; in general, it slopes gently toward the Central Plateau in the east, whereas it slopes very steeply toward the Rift province in the west (fig. 5). Because the base level of erosion in the Rift province has been lowered by continuing structural subsidence, the westward drainage of the Mountain Ridge province has been rejuvenated frequently. Thus, the streams have cut farther and farther eastward into the Central Plateau, capturing additional areas for the drainage basin of the Rift (Burdon, 1959, p. 12). The highest altitudes in the country (about $1,850 \mathrm{~m}$ ) are in the southern part of the Mountain Ridge province, in the Jibal ash Sharāh.

The Central Plateau is bordered on the west by slopes that rise westward to the Mountain Ridge province; in the north and in the east, the Central Plateau falls to the flat, wide southeast-striking $\mathrm{Al}$ Azraq-Wādī as Sirḩān Basin, which includes the oasis of Al Azraq in its northeastern part. The hori- 


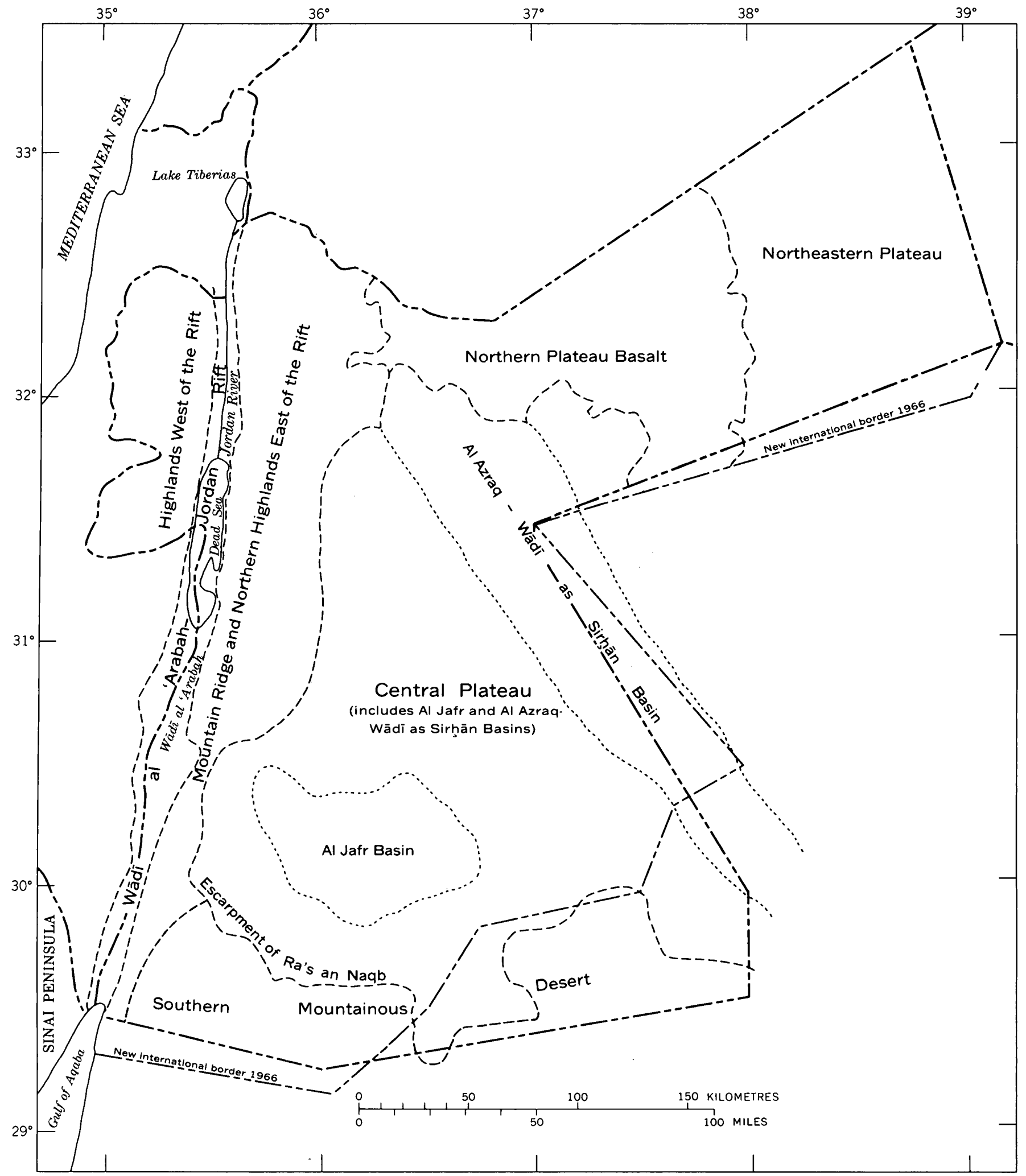

FIGURE 1.-Index map showing physiographic-geologic provinces, Jordan. 


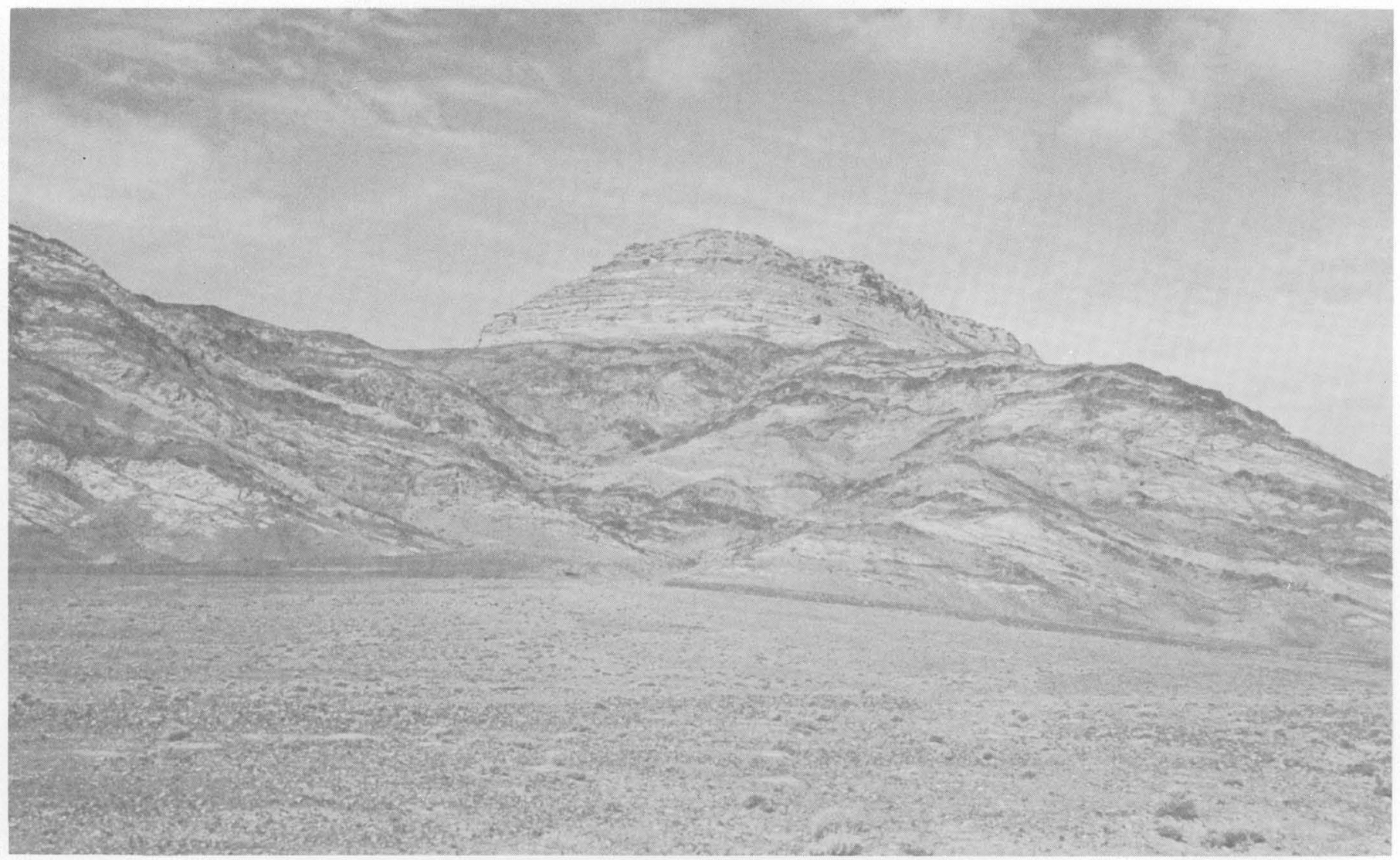

FIGURE 2.-Precambrian granodiorite and dikes and overlying Cambrian sandstone, approximately $5 \mathrm{~km}$ north-northwest of Al Quwayrah, southern Jordan.

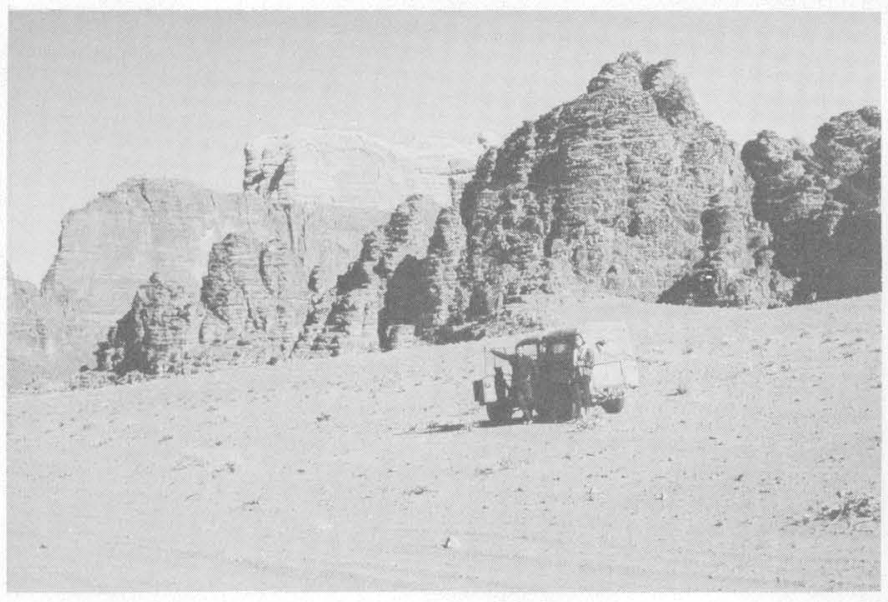

FIGURE 3.-Cambrian and Lower Ordovician sandstone, approximately $8 \mathrm{~km}$ south-southeast of Ramm police station (long $35^{\circ} 25^{\prime}$ E., lat $29^{\circ} 35^{\prime}$ N.), southern Jordan.

zontal or gently dipping limestone, marl, and chert beds of the Upper Cretaceous and lower Tertiary sequence form tableland scarps; chains of outliers (fig. 6) are partly covered or surrounded by the debris of arid weathering. The outliers reach al- titudes of about $1,000 \mathrm{~m}$ above sea level. To the south, the altitude of the Central Plateau gradually lowers to about $850 \mathrm{~m}$ above sea level and is lowest in the wide $\mathrm{Al} \mathrm{Jafr}$ Basin, which is about $150 \mathrm{~km}$ long in a northwest direction and about $100 \mathrm{~km}$ wide. The central part of this basin is an extensive mudflat $\left(240 \mathrm{~km}^{2}\right)$. Farther south, the altitude of the Upper Cretaceous and lower Tertiary rock sequence of the Central Plateau is more than 1,500 $m$ at the escarpment of Ra's an Naqb, the boundary between the Central Plateau and the Southern Mountainous Desert provinces. Areas of many hundreds of square kilometers in the central parts of the Central Plateau are covered by desert pavement consisting of wind-eroded chert residue, the flint-strewn "Hamada" desert. Drainage in the western part of the Central Plateau is to the west where extensive drainage areas have been captured for the Rift by the headward erosion of the Wādi al Mawjib, Wādī al Karak, Wādī al Hुasā, and Wādi Dुānā drainage systems. In the southern part of the Central Plateau, drainage is from all sides 


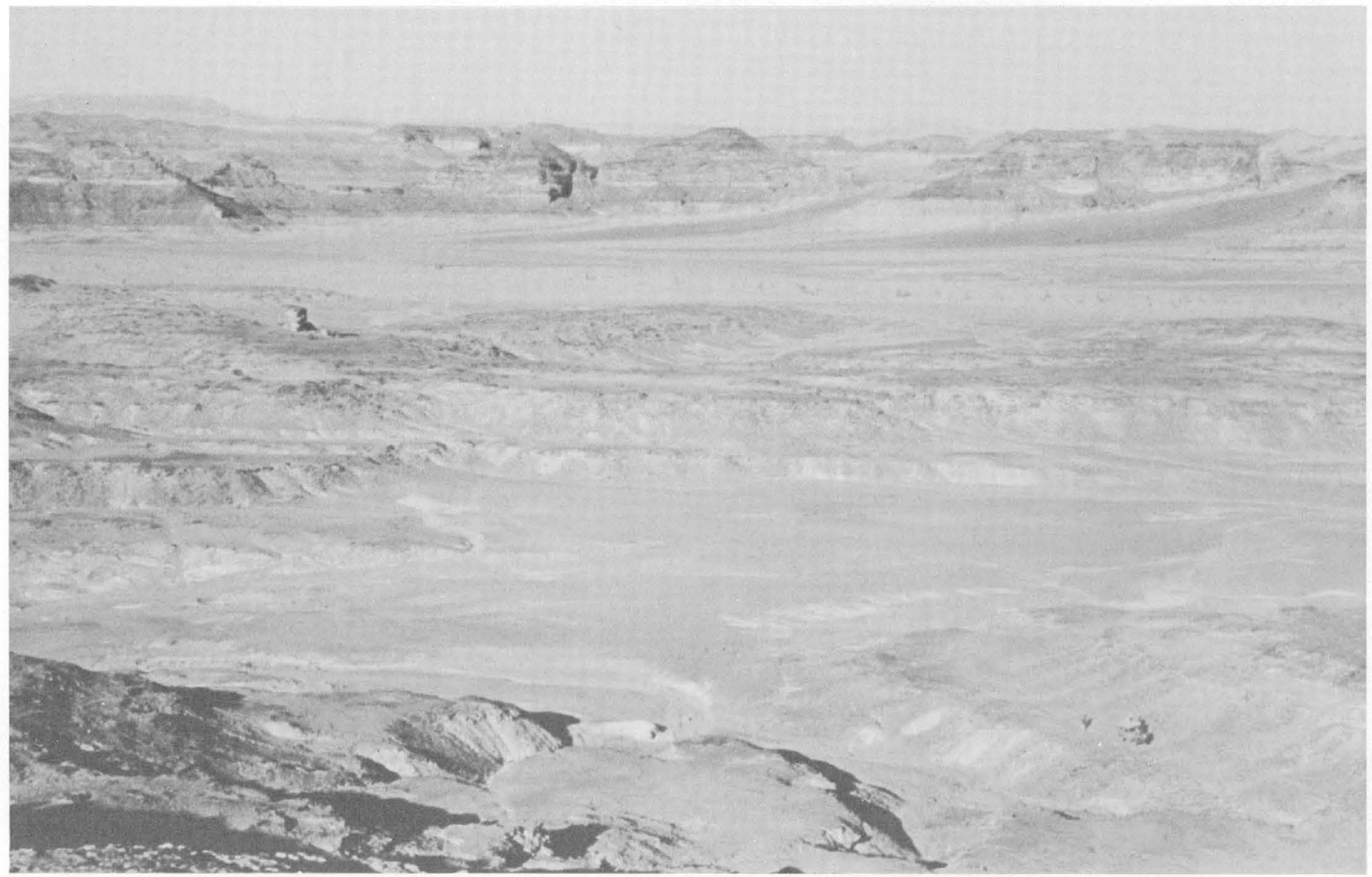

FIGURE 4.-Middle and Upper Ordovician sandstone and shale, approximately $10 \mathrm{~km}$ northwest of Maḩațțat al Mudawwarah, southern Jordan.

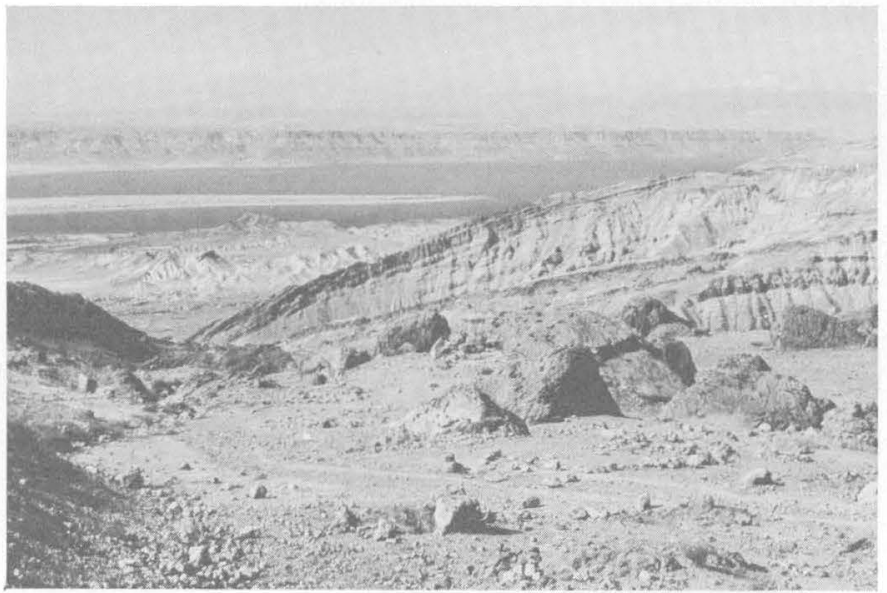

Figure 5.-Beginning of flexure in Upper Cretaceous limestone and marl, east of the Al Lisān Peninsula. Dead Sea in the background.

to the center of the Al Jafr Basin; in the east and north, drainage is northeast into the Al AzraqWādī as Sirḩān Basin.

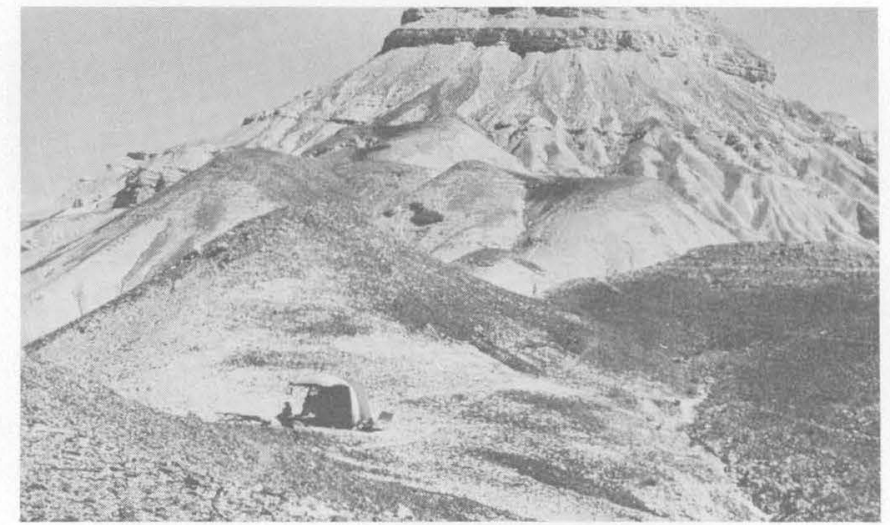

FIgURE 6.-Outlier Tुuwayyil ash Shihāq of Upper Cretaceous and lower Tertiary limestone, marl, and chert, approximately $30 \mathrm{~km}$ southeast of Maḩațțat al Hasā, central Jordan.

The Northern Plateau Basalt province in Jordan covers an area of approximately $11,000 \mathrm{~km}^{2}$, east of the northern part of the Al Azraq-Wādì as Sirḩān Basin. The Plateau Basalt forms an almost inac- 
cessible landscape of flows, fissure effusions, and isolated volcanoes (fig. 7). The basalt of many flows has been cracked by insolation and broken into blocks. This shield of basalt gradually lowers from altitudes of about $1,100 \mathrm{~m}$ at the Syrian-Jordanian border on the north to approximately $550 \mathrm{~m}$ in the south, close to the Wādi as Sirhān Basin. Drainage is south and southwest to Wādī as Sirhān; in the eastern part of the Plateau Basalt drainage is east and southeast.

East of the Plateau Basalt, the Northeastern Plateau province extends as a monotonous quasipeneplained landscape far eastward across the Iraq border, north into Syria, and south into Saudi Arabia. This area is almost entirely occupied by calcareous and siliceous lower Tertiary sedimentary rocks, locally covered by upper Tertiary calcareous and sandy rocks and by Quaternary unconsolidated sediments. The drainage pattern obviously follows zones of structural weakness-mainly northwest, and, less pronounced, north-northwest and eastnortheast (fig. 8).

The Wādĩ al 'Arabah-Jordan Rift (the Rift province) is a narrow depression that extends from the Gulf of Aqaba for approximately $360 \mathrm{~km}$ north to Lake Tiberias; it represents but a small fraction of the East African-Asia Minor Rift system. Unconsolidated sediments of Neogene (Miocene and Pliocene) and, chiefly, Quaternary age occupy most of the floor of the Rift province. The floor of the Rift rises gradually from the Gulf of Aqaba to altitudes of $250 \mathrm{~m}$ above sea level at the watershed of Jabal ar Rīshah in the central Wādī al 'Arabah. From there the floor falls gently northward to the surface of the Dead Sea, $392 \mathrm{~m}$ below sea level. The Dead Sea covers an area of $997 \mathrm{~km}^{2}$; it is $80 \mathrm{~km}$ long and averages $15 \mathrm{~km}$ wide. North of the $\mathrm{Al}$ Lisān Peninsula (fig. 9), the Dead Sea reaches its maximum depth of $401 \mathrm{~m}$; thus, the maximum depth of the depression is $793 \mathrm{~m}$ below sea level. From the Dead Sea, the direction of the depression turns slightly from N. $15^{\circ} \mathrm{E}$. to about N. $5^{\circ} \mathrm{E}$. From the mouth of the Jordan River at $392 \mathrm{~m}$ below sea level, the 105-km-long Jordan River valley rises to $212 \mathrm{~m}$ below sea level at Lake Tiberias.

In the Highlands West of the Rift, structural upwarps (of a folded and faulted, mainly Upper Cretaceous-lower Tertiary rock sequence) and drainage systems (eastward to the Jordan River valley and westward to the Mediterranean Sea) have combined to form a mountainous diversified landscape (fig. 10). The watershed between the

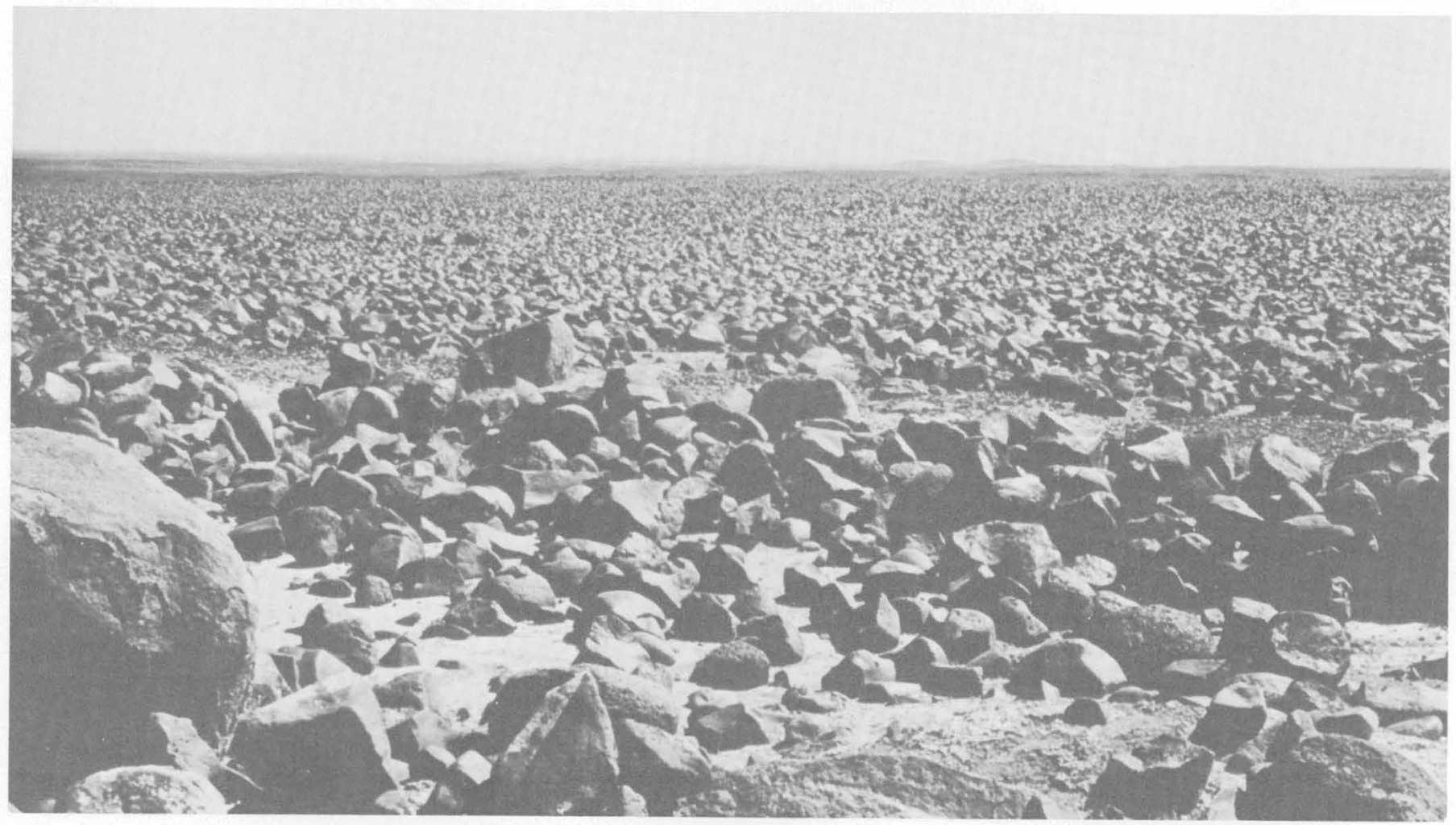

FIgURE 7.-Basalt flow cracked by insolation, blocks subangularly shaped by wind corrasion; approximately $200 \mathrm{~km}$ east of 'Ammān, northeast Jordan. 


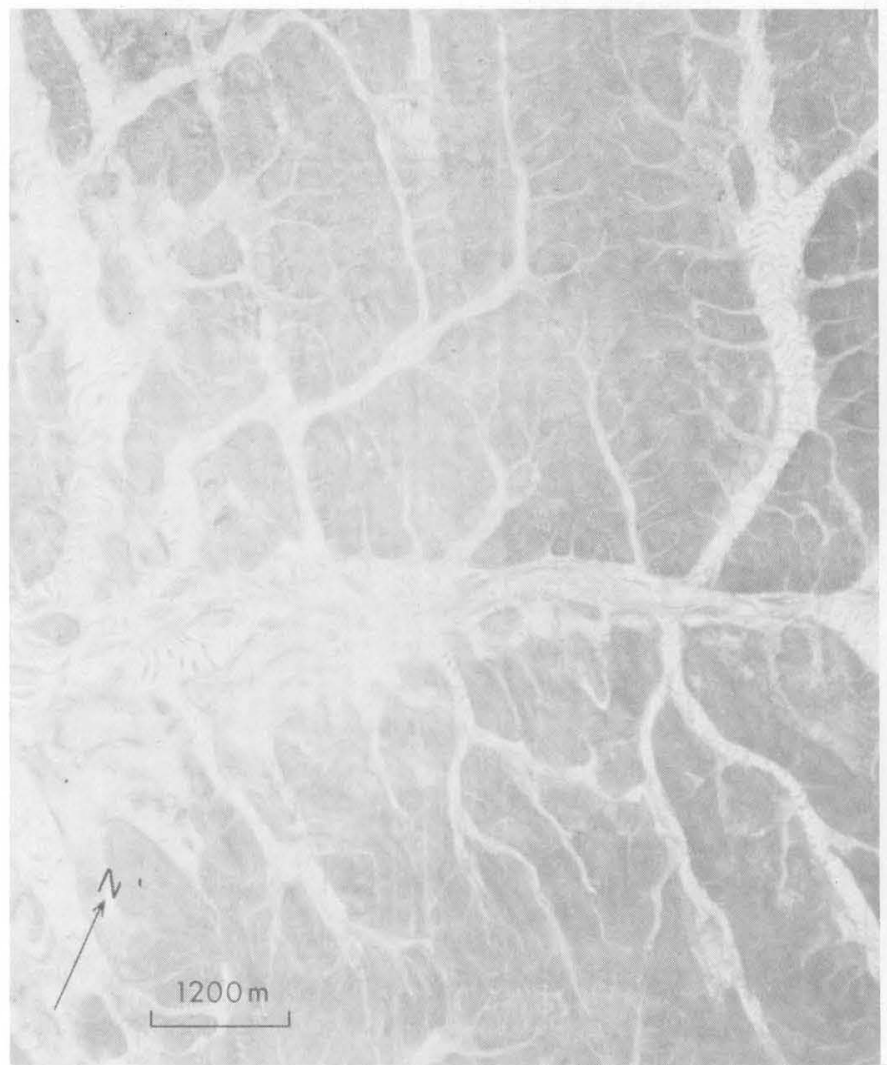

Figure 8.-Aerial view of wadis and mudflats that follow structural pattern in Tertiary limestone; approximately $250 \mathrm{~km}$ east-northeast of Al Mafraq.

Dead Sea catchment area and the Mediterranean Sea trends approximately north-northwest from the Al Khalil (Hebron) region through BethelemJerusalem-Rāmallah to the Nābulus (Nablus) region, and reaches altitudes of about $1,000 \mathrm{~m}$.

\section{GEOLOGIC HISTORY AND PALEOGEOGRAPHY}

The small exposures of highly metamorphosed rocks along the southern Wādī al 'Arabah seem to represent the remnants of early(?) Proterozoic geosynclinal sedimentation and volcanism. The intrusion of gabbroic rocks, diorite, quartz diorite, granodiorite, and aplite granite, which are the main constituents of the Precambrian basement complex in south Jordan, may be considered the cause of their katazonal metamorphism. As isotope determinations have revealed, the plutonic rocks are of late Proterozoic age. The age succession of the different types of igneous rocks has not been clarified. A great many differentiated dike rocks were intruded at different times into the solidified plutonites, along dominant zones of tension that strike

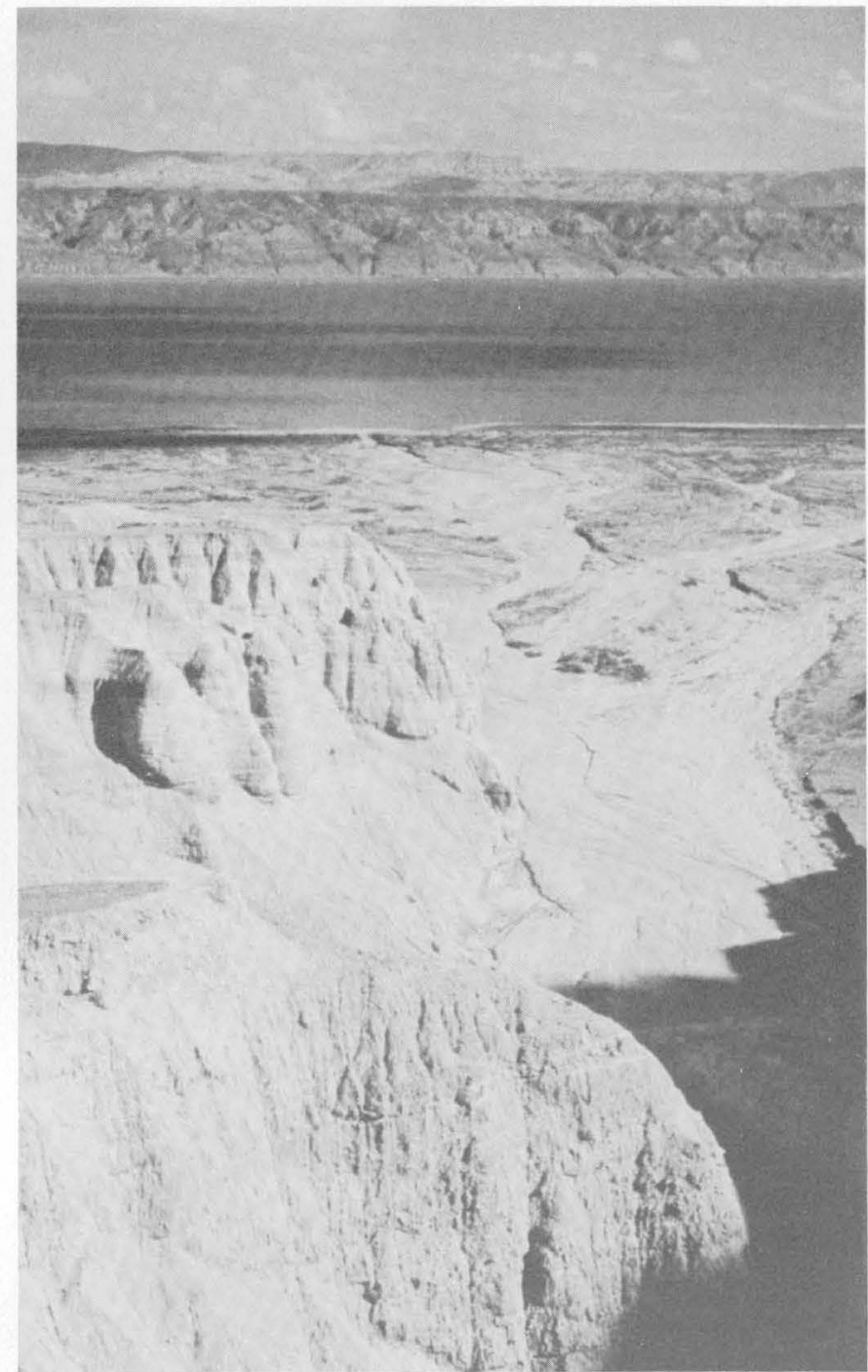

Figure 9.-The Wādĩ al 'Arabah-Jordan Rift province at its lowest point as viewed from the west. Upper Pleistocene terraced coarse clastic deposits are in foreground; opposite shore of the Dead Sea is the eastern edge of the rift valley showing a Triassic, Jurassic, and Cretaceous rock sequence.

northeast, east, and north. The number of dikes per square kilometer of exposed Precambrian basement complex increases considerably from southeast Jordan westward toward the Wādi al 'ArabahJordan geosuture (zone of the structural weakness).

Uplift and erosion preceded the deposition of sediments of latest Proterozoic age, which were affected merely by epizonal metamorphic processes and do not indicate alpine-type orogenesis. All these Proterozoic rocks were then intruded by many differentiated dike rocks.

At the beginning of the Cambrian, a peneplain formed in southern Jordan east of the Rift; highly 


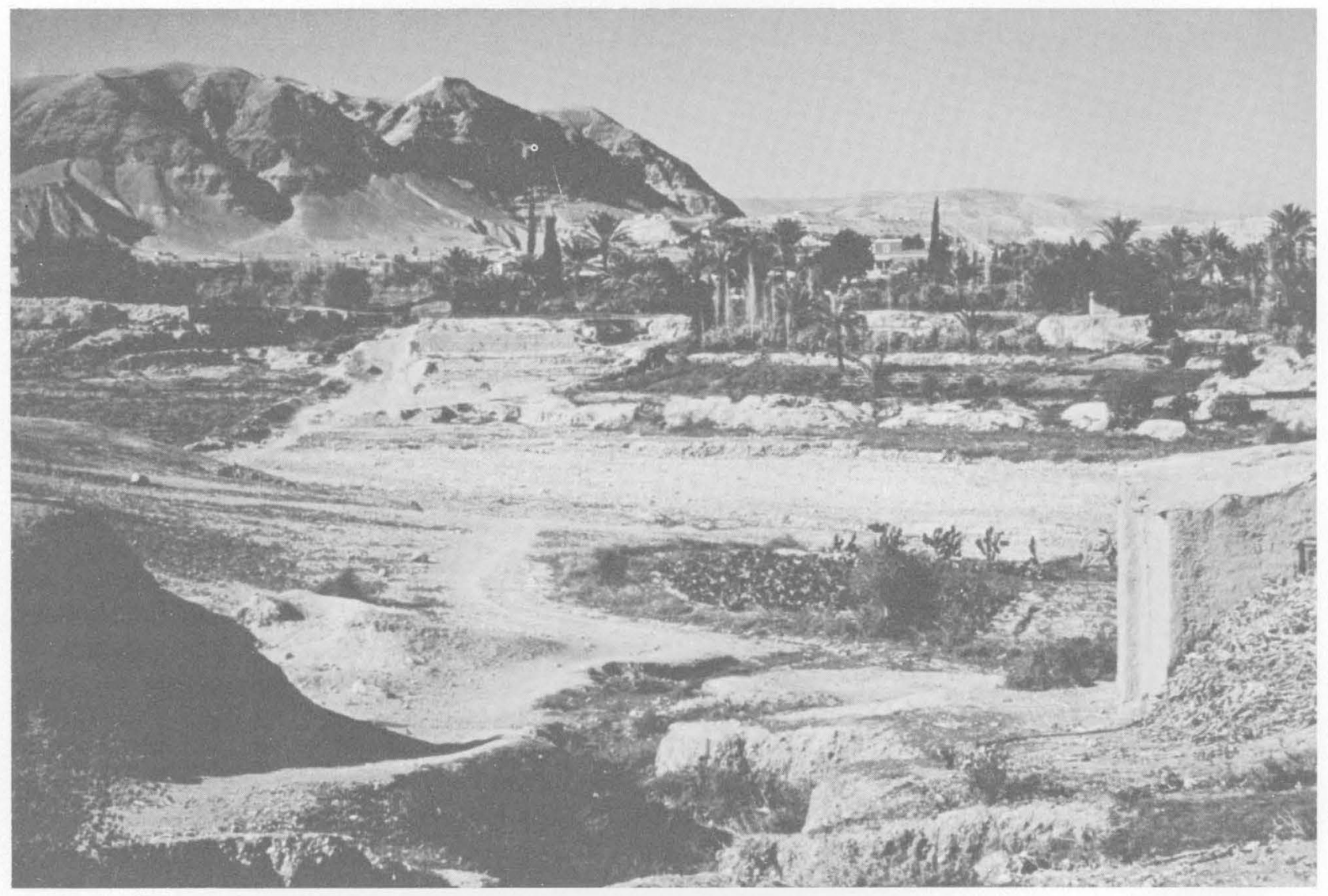

Figure 10.-Upper Cretaceous rocks, western edge of Wādī al 'Arabah-Jordan Rift province, Mount of Temptation west of Arīhā (Jericho).

metamorphosed "roof rocks" and remnants of upper Proterozoic sedimentary rocks were eroded away. In the area of the Wādī al 'Arabah-Jordan geosuture, however, a surface of pronounced relief was cut in the Precambrian rocks, and quartz porphyry lavas seem to have erupted dominantly along this geosuture from the latest Proterozoic until deposition of Cambrian sediments.

Because of Precambrian tectonism, the metamorphosed rocks and upper Proterozoic sedimentary rocks in the area of Wādī al 'Arabah were preserved from complete erosion prior to the deposition of Cambrian sandstone. For this and other reasons, it is therefore thought that the formation of the Wādì al 'Arabah-Jordan geosuture dates back to Precambrian time.

Since the beginning of the Cambrian, the paleogeographic evolution of Jordan has been influenced by three dominant features: (1) The Tethys Sea in the west and northwest, which transgressed several times over parts of, or over all of Jordan, (2) the Wādī al 'Arabah-Jordan geosuture, which separates the Palestine block on the west from the Trans-
Jordan block on the east, and (3) the Nubo-Arabian Shield in the southeast and south, from which mechanical and chemical weathering products were transported onto the shelf of the Tethys Sea and where, during certain periods, continental clastic sediments were deposited.

The clastic sedimentary rocks of the Lower Cambrian are of continental origin, insofar as is known from exposures in south Jordan and along the Rift. These Lower Cambrian rocks overlie either peneplained Precambrian plutonites or, as in the Wādi al 'Arabah zone of the geosuture, a surface of pronounced relief cut in different Precambrian rocks.

During the latest Early to Middle Cambrian, an early transgression of the Tethys Sea advanced to the east side of the central part of the Wādi al 'Arabah. The pattern of different lithofacies (marine calcareous, marine sandy, continental sandy) was influenced by the north-south course of the geosuture between the Palestine and Transjordan blocks (fig. 11). A regression is indicated in the Middle and Late(?) Cambrian by continental sandstones above the Tethyan marine sedimentary rocks. 


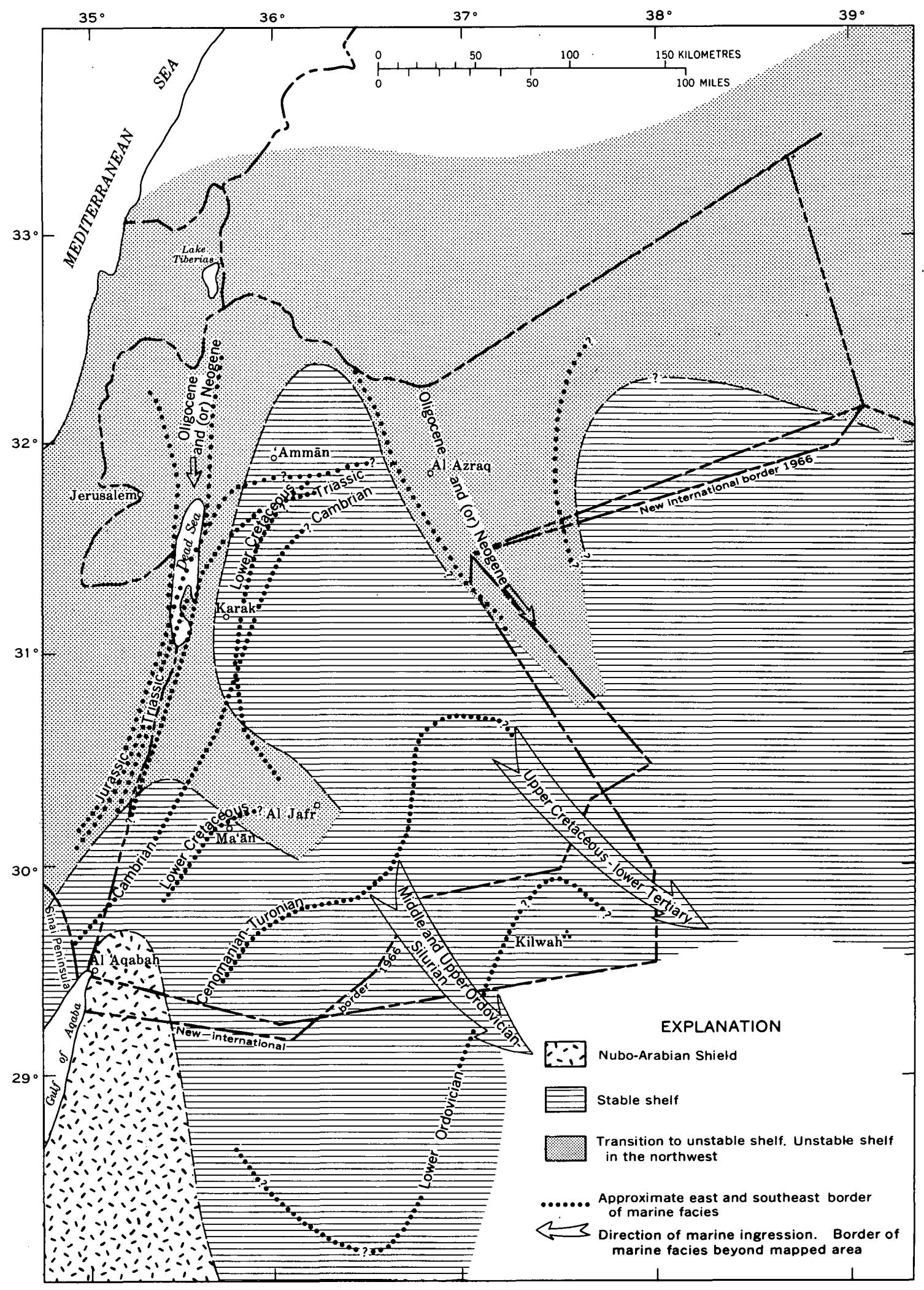

FIGURE 11.-Paleogeography of Jordan. 
During the Early Ordovician, the Tethys Sea again transgressed over flat land areas, entering southeast Jordan and northwest Saudi Arabia, far beyond its Cambrian shoreline. In a shallow marine environment of deposition, mainly fine-grained sandy and argillaceous material accumulated during the Middle and Late Ordovician and the Early Silurian. In southeast Jordan, continental influence on the sedimentation is suggested by a red-brown sandstone sequence between the marine Lower Silurian and the marine Upper Silurian clastic rocks. The marine environment of deposition continued also in the Early Devonian. Calcareous and sandy rocks of this age are found about $100 \mathrm{~km}$ southeast of the southeast corner of Jordan. Middle and Upper Devonian sedimentary rocks have not been identified.

Carboniferous (lower Westphalian A-Namurianupper Viséan) sandstones and calcareous sandstones were deposited in a littoral(?)-continental environment in north Jordan and probably also in west Jordan. Rocks of Permian age have not been confirmed.

Another transgression of the Tethys Sea to the southeast occurred during the Early and Middle Triassic. The sea advanced from the west and northwest to the area just east of the Dead Sea, where Triassic littoral, lagoonal, and continental(?) sedimentary rocks disconformably overlie lower Paleozoic clastic rocks.

After a regression during the Late Triassic and Early Jurassic (Rhaetian and Liassic), the ocean advanced once more during the Middle Jurassic. Jurassic shorelines probably were just west of and approximately parallel to the borders of the Triassic transgression, whereas erosion continued on the land farther east and south. Again, the eastern borders of the marine depositional environment and the thickness of the deposited sediments were remarkably influenced by the meridional zone of structural weakness (fig. 11).

Renewed epeirogenic uplift and erosion, and local volcanism, probably during the Late Jurassic (Kimmeridgian), preceded Early Cretaceous deposition. Dominantly clastic rocks of Early Cretaceous age therefore overlie the Paleozoic, Triassic, or Jurassic formations with a regional angular unconformity. During the Early Cretaceous, the marine depositional environment dominated the northwest part of Jordan, and a transgression during the Albian reached the area east of the Jordan River. Farther east and to the south, clastic sediments of continental origin were deposited.

Beginning in the Late Cretaceous (Cenomanian), a regional transgression started to spread over land areas far beyond the borders of the Albian sea. Closer to the Nubo-Arabian Shield in the southeast, however, the continental depositional environment of sandy sedimentation, which formed in the Early Cretaceous, continued in the Late Cretaceous, including the Santonian. The marine calcareous, marly, siliceous rock units of the Cenomanian, Turonian, Santonian, Campanian, and Maestrichtian therefore overlie these continental sandstones with onlap toward the southeast. In the areas occupied by the sea, great thicknesses of sediments accumulated in basins, particularly along the Wādi al 'ArabahJordan geosuture, and in the Al Jafr and Al AzraqWādì as Sirḩān Basins (fig. 11). The pattern of gentle swells characterized by phosphorites, oyster lumachelles, and chert layers, and of local euxenic basins characterized by thick bituminous limestones and marls, was pronounced during the Late Cretaceous (Campanian, Maestrichtian, and Danian) and continued during the Paleocene and early Eocene.

During the late Eocene, thin calcareous sediments were deposited in a shallow marine depositional environment. They are found only locally in the basins where subsidence continued, but all of Jordan probably remained covered by the sea.

During the Oligocene, taphrogenic (rift-forming) structural movements started on the southern east side of the Wādi al 'Arabah-Jordan geosuture and resulted in uplift, emergence, and continental erosion. The subsequently formed graben zone (rift valley), and extensive parts of north and northeast Jordan still remained covered by the Tethys Sea.

In the Neogene, paleogeographic conditions in the Wādi al 'Arabah-Jordan geosuture were dependent on the relation between taphrogenic subsidence and sediment accumulation. The rift valley which formed along the geosuture was either occupied by freshwater lakes draining west to the Tethys Sea, or it formed an inland depression of terrestrial or lacustrine sedimentation, or it was entered by marine waters. During a time in the Miocene-Pliocene, the Mediterranean Sea may have been linked with the Red Sea through the Gulf of Aqaba and Wādi al 'Arabah-Jordan rift valley and through the Beisan depression (pl. 3). A Miocene transgression from the north reached to the Al Azraq-Wādi as Sirḩān Basin and to northeast Jordan beyond the Djebel ed Drouz basalt flows. In the area of deepest structural subsidence within the rift valley (Dead Sea-Ghawr as Șãfi area), evaporites about 4,000 m thick were deposited during the Miocene(?)-Pliocene-early Pleistocene (?). During the Pliocene-Pleistocene time 
transition and intra-Pleistocene time, several phases of major taphrogenic movements occurred. During Villafranchian and Acheulian time thick fluviolacustrine sediments and volcanic material accumulated in the Wādì al 'Arabah-Jordan Rift. Lacustrine sediments and fluviatile sand, gravel, and conglomerate also characterize late Pleistocene and Holocene deposition within the graben.

Apparently during the middle Tertiary, folding, mainly in the west and in the north, was contemporaneous with and related to the beginning of the Jordan Rift taphrogenesis. The folding was followed by regional arching, and, during the Pliocene and Pleistocene, by several phases of major faulting.

In the areas adjacent to the rift valley and in southeast Jordan, which had been emergent since the Oligocene, and in the large basins in northern, northeastern, and eastern Jordan, which emerged not earlier than the Miocene and Pliocene(?), denudation has prevailed until the present time. Weathering products were transported in great quantities either into the rift valley or into the extensive depressions in east Jordan. These depressions were partly covered by fresh-water or brackishwater lakes during pluvial periods in the Pleistocene; fluvial conglomerates spread over extensive areas along the eastern slopes of the highlands which border the east side of the Wādĩ al 'Arabah-Jordan Rift province.

\section{PRECAMBRIAN BASEMENT COMPLEX}

\section{METAMORPHIC ROCKS}

Small outcrops of garnet-biotite gneiss, biotitehornblende gneiss, and biotite schist have been reported from the east side of the southern Wādi al 'Arabah (Lartet, 1869; Blake, 1936, 1939; Burdon, 1959; Bender 1968a). These rocks are found as stoped blocks, or inclusions, within the surrounding Precambrian intrusive rocks-for example, the wellexposed rocks in the lower course of the Wādi Abū Barqā north of Gharandal (fig. 12).

\section{IGNEOUS ROCKS}

The important Precambrian igneous rocks have been distinguished on the "Geological Map of Jordan" sheet "Aqaba-Ma'an" (Bender and others, 1968), and are described by Bender (1968a) and van den Boom and Rösch (1969).

Hornblendite and hornblende gabbro were found west of the Jabal al Muhtadi, on the western slopes of the Jabal Darbah, in the Wâdi Darbah, and on the west side of the Tilāl Turaybin-all on the east

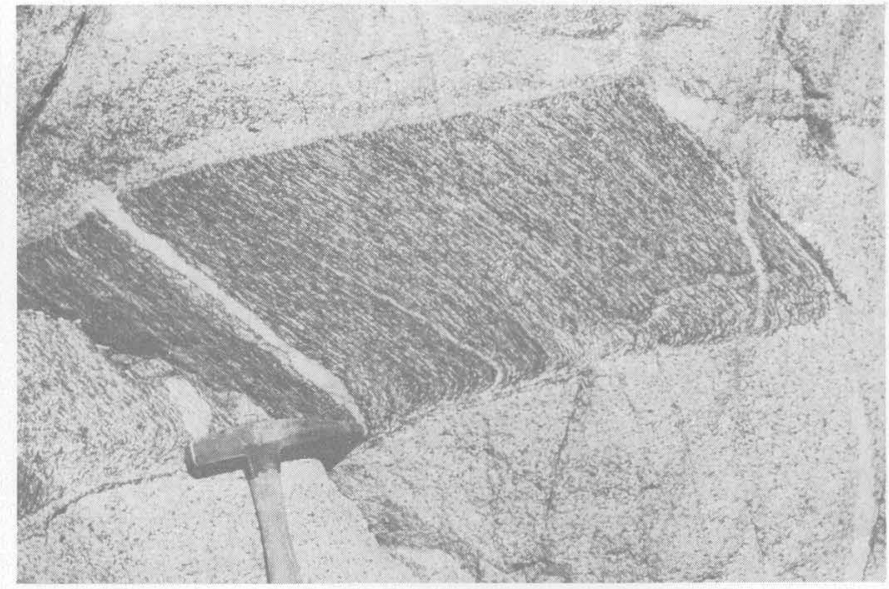

FIgURE 12.-Biotite schist in aplite granite; lower Wādī Abū Barqā, east side of central Wādī al 'Arabah.

side of the southern Wādì al 'Arabah. Three potassium-argon age determinations by Lenz and others (1972) resulted in ages of $611 \pm 9$ million years (hornblende), $584 \pm 8$ m.y. (biotite), and $564 \pm 12$ m.y. (biotite).

Diorite in the lower Wādi Qunayyah near the southeast shore of the Dead Sea was also dated by Lenz and others (1972) as $594 \pm 8$ m.y. and $585 \pm 8$ m.y. old by two potassium-argon age determinations on biotite.

Quartz diorite has been found by van den Boom and Lahloub ${ }^{16}$ in the Jabal al 'Urf area approximately $38 \mathrm{~km}$ north-northwest of $\mathrm{Al}$ 'Aqabah (type locality) and was mapped also in other places in south Jordan. Pink and gray varieties of granodiorite are extensively exposed in the Wādi al Yitm (Wādī al Yutm) area north of $\mathrm{Al}$ 'Aqabah and are the equivalent of the pink granite and gray granite of Ionides and Blake (1939).

Biotite aplite granite is the most common plutonic rock in south Jordan, and is the "granite" of Blanckenhorn (1914), Fuchs (1916), and Blake (1936). Physical age determinations using the potassium-argon method on biotite resulted in ages of $590 \pm 20$ m.y. (Dr. Snelling, Oxford Univ., 1965, in Bender 1968, p. 20), and $592 \pm 10$ m.y. and $582 \pm 8$ m.y. (Lenz and others, 1972). The samples were collected from a roadcut $15 \mathrm{~km}$ north of $\mathrm{Al}$ 'Aqabah.

Two-mica aplite granites have been identified at long $35^{\circ} 12^{\prime} 20^{\prime \prime} \mathrm{E}$., lat $29^{\circ} 45^{\prime} 29^{\prime \prime} \mathrm{N}$., the type locality in the area of Jabal al 'Urf; alaskite has also been

\footnotetext{
16 Boom, Günter van den, and Lahloub, Mahmoud, 1964, Geological and petrological investigations of the igneous rocks in the area of Quweira, south Jordan: German Geol. Mission in Jordan, unpub. rept. (Fed. Rep. Germany Geol. Survey, Hannover.)
} 
identified west of the Ma'ān-Al 'Aqabah highway in the area of Wādĩ al Yitm (van den Boom and Lahloub, $1964^{16}$ ).

A great variety of dike rocks (fig. 13) intruded

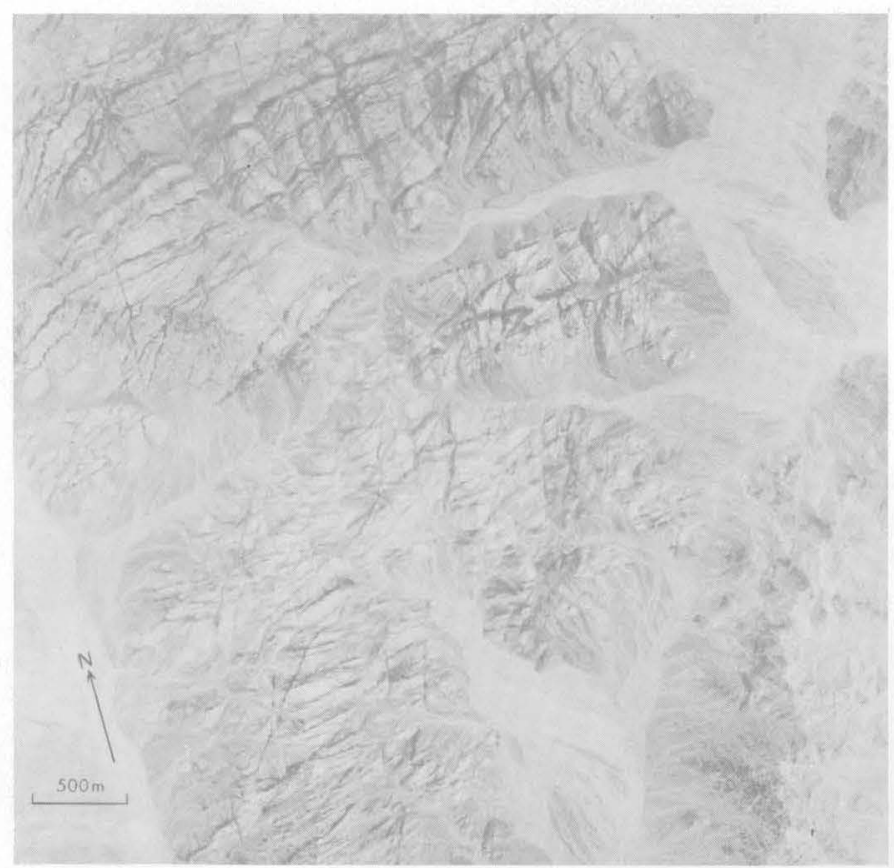

FIGURE 13.-Mafic, intermediate, and silicic dikes in alaskite (southeast and northeast corners of aerial photograph) and in granodiorite and quartz diorite; approximately $15 \mathrm{~km}$ west-southwest of Al Quwayrah, southern Jordan.

these plutonites during several phases: quartz dikes, pegmatite, granite-aplite, granite porphyry, quartz porphyry, felsite, quartz-orthoclase porphyry, plagioclase porphyry, kongadiabase (diabase containing quartz), quartz diorite porphyry, orthoclase porphyry, minette, vogesite, kersantite, spessartite, porphyrite, and diabase (van den Boom and Lahloub, $1964^{16}$ ). The dominant strike directions of these dikes are northeast and east-northeast, and to a lesser degree, east and north. The quantity of dikes decreases with increasing distance eastward from the southern rift zone (Wādī al 'Arabah). None of the dikes, with the exception of some quartz porphyries, invade overlying Cambrian strata.

\section{UPPER PROTEROZOIC SEDIMENTARY ROCKS}

The Saramuj Conglomerates (Blanckenhorn, 1912) and the Slate-Graywacke Series (Bender, 1965) overlie and are separated by a profound erosion surface from the plutonic rocks. These units are restricted to local exposures on the east side of the Wādì al 'Arabah-Dead Sea part of the Rift province. The Saramuj Conglomerates consist of well-rounded boulders and gravel derived from the older igneous magmatites and metamorphic rocks; the conglomerates have a partly brecciated, arkosic sandy cement and alternate with coarse and fine, somewhat arkosic, sandstone beds. They show evidence of slight metamorphism (epizonal metamorphism), and they are greatly faulted and displaced, but no alpine-type folding was observed. In the area of Wādì Abū Barqā (approximately $5.5 \mathrm{~km}$ north-northeast of Gharandal) the Saramuj Conglomerates are more than $200 \mathrm{~m}$ thick and are conformably overlain by the Slate-Graywacke Series, which is more than $200 \mathrm{~m}$ thick. The Slate-Graywacke Series consists of gray-green and red-brown, hard, dense, commonly silicified sandy or silty slates that alternate with subgraywackes. This series is in turn overlain with pronounced angular unconformity by Cambrian sedimentary rocks (fig. 14). Both the Saramuj Conglomerates and the

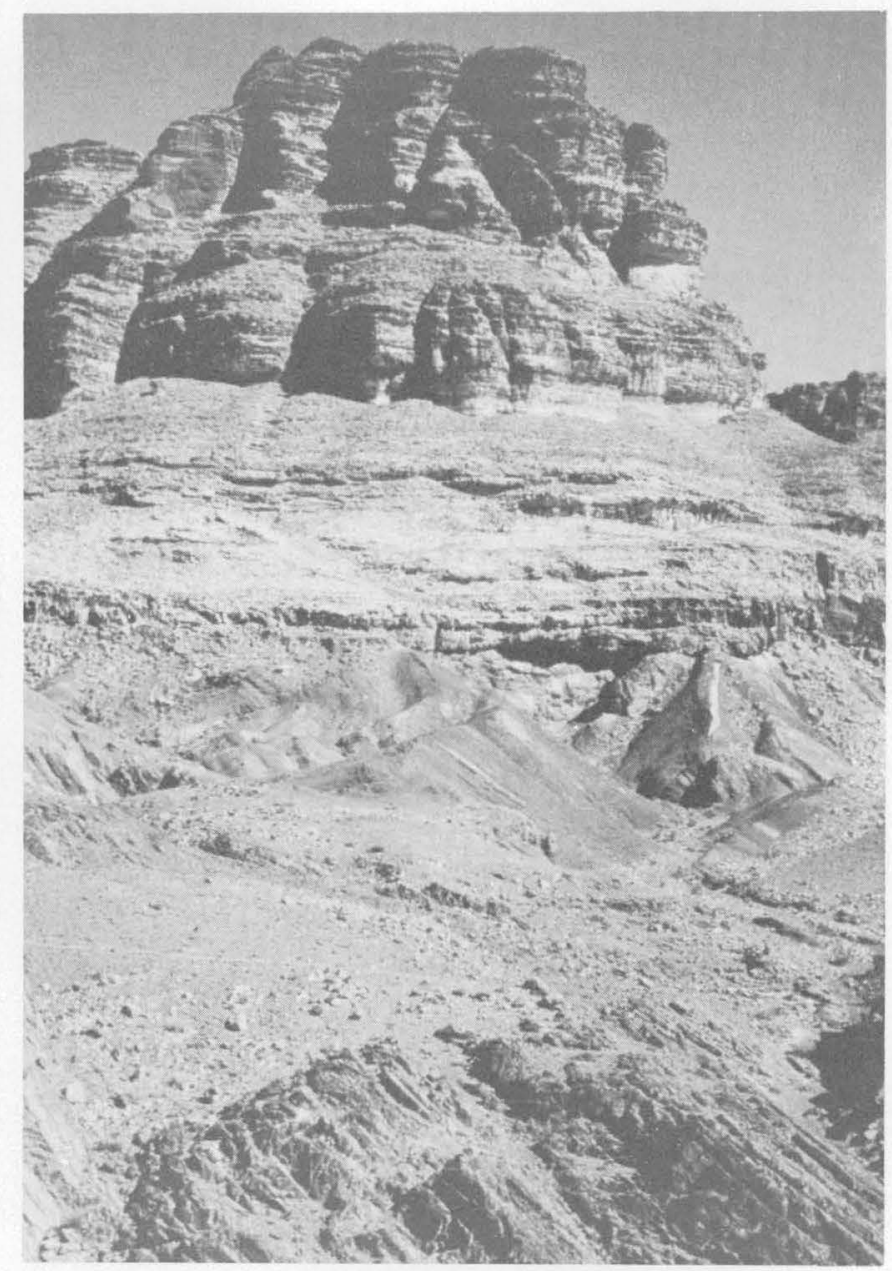

Figure 14,-Angular unconformity between the upper Proterozoic Slate-Graywacke Series and Cambrian sandstone; middle course of Wādī Abū Barqā on the east side of Wādī al 'Arabah. 
Slate-Graywacke Series are intruded by numerous dike rocks, such as diabase, porphyrite, and quartz porphyry; only some of the quartz porphyry dikes invade the Cambrian clastic rocks.

\section{UPPER PROTEROZOIC-PALEOZOIC VOLCANIC AND ASSOCIATED ROCKS}

North of Gharandal along the east side of the Wādi al 'Arabah part of the Rift province, large masses of irregular stocks and sills and dikes of quartz porphyry and some porphyrite crop out, either within or above the magmatites, within the upper Proterozoic strata, or locally within the Lower Cambrian clastic rocks (fig. 15; Bender, $1965,1968 b)$.

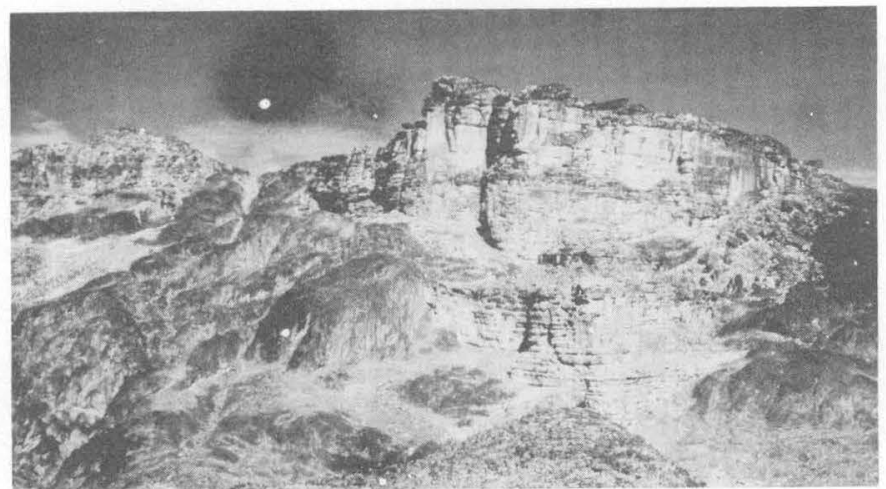

FIGURE 15.-Intrusion of quartz porphyry into Cambrian sandstone; upper course of Wādī Musaymīr, east side of central Wädī al 'Arabah.

Ignimbrites and clastic materials in a volcanic matrix were found in the Wādi Abū Khushaybah area approximately $22.5 \mathrm{~km}$ north-northeast of Gharandal, at the east side of Wādi al 'Arabah (Bender, 1968b, pl. 14). The age of one such ignimbrite, determined by the potassium-argon wholerock method, is $471 \pm 7 \mathrm{~m} . y$. (Lenz and others, 1972).

From an interpretation of these data and of the mapping results it may be concluded that during the latest Precambrian, quartz porphyry volcanism took place along the southern part of the Wādi al 'Arabah-Jordan geosuture. These quartz porphyry rocks were subjected to erosion at the beginning of Cambrian sedimentation. Locally, however, volcanism continued while Lower Cambrian clastic rocks were deposited.

\section{POST-PROTEROZOIC STRATIGRAPHY AND VOLCANISM}

The lithostratigraphic subdivision of the sedimentary rocks of Jordan, their time-stratigraphic correlation, and the general character of depositional environment are shown on plate 2 .

To avoid confusion, the use of the many ill-defined rock-unit and formation names introduced by various authors has been restricted. Instead, lithologic or paleontologic descriptive terms have been used for lithostratigraphic units that have been defined as to their lower and upper contacts, areal extent, and their position in the time-stratigraphic scale.

\section{PALEOZOIC ERA}

Cambrian sedimentary rocks are exposed in a belt that extends from the southern end of the country along the east side of Wādi al 'Arabah to the Dead Sea (pl. 1). Cambrian sedimentation started in a continental environment in which basal conglomerates (as much as $50 \mathrm{~m}$ thick) were deposited with angular unconformity (fig. 16) above a pronounced erosional hiatus. The conglomerates are only found in the area of the geosuture where they fill in the valleys of a distinct surface cut in the Precambrian basement complex. Conglomerates are absent in the area east of the Wādi al 'Arabah, where bedded arkosic sandstone (as much as $200 \mathrm{~m}$ thick) rests on peneplained rocks of Precambrian age (fig. 16).

Above the bedded arkosic sandstone, marine transgressive beds crop out along the east side of the Wâdī al 'Arabah between the Dead Sea and Gharandal. Near Gharandal these marine beds are white

Physical age determinations of samples of upper Proterozoic-Paleozoic volcanic and associated rocks

\begin{tabular}{|c|c|c|c|c|}
\hline Rock & Location & $\begin{array}{c}\text { Age } \\
\text { (million years) }\end{array}$ & Method & Reference \\
\hline Quartz porphyry mass _-- & $\begin{array}{l}\text { Jabal at Tayyibah at mouth } \\
\text { of Wādí Mūsá into Wādĩ al } \\
\text { 'A rabah. }\end{array}$ & $574 \pm 8 \ldots$ & $\mathrm{K}: \mathrm{Ar}$, whole rock & Lenz and others 1972. \\
\hline Porphyrite mass & $\begin{array}{l}2 \mathrm{~km} \text { east of ruins of Faynān } \\
\text { (Feinān). }\end{array}$ & $542 \pm 8 \ldots$ & - - do - & Do. \\
\hline Quartz porphyry mass --- & Wādì Quşayb .... & $530 \pm 50$ & $\mathrm{Rb}: \mathrm{Sr}$ & $\begin{array}{l}\text { Dr. Snelling, written } \\
\text { commun., } 1966 .\end{array}$ \\
\hline $\begin{array}{l}\text { Quartz porphyry stock in } \\
\text { Lower Cambrian sand- } \\
\text { stone. }\end{array}$ & Wādì Musaymīr _.......... & $525 \pm 10 \ldots$ & $\mathrm{K}:$ Ar, whole rock & Lenz and others 1972. \\
\hline
\end{tabular}




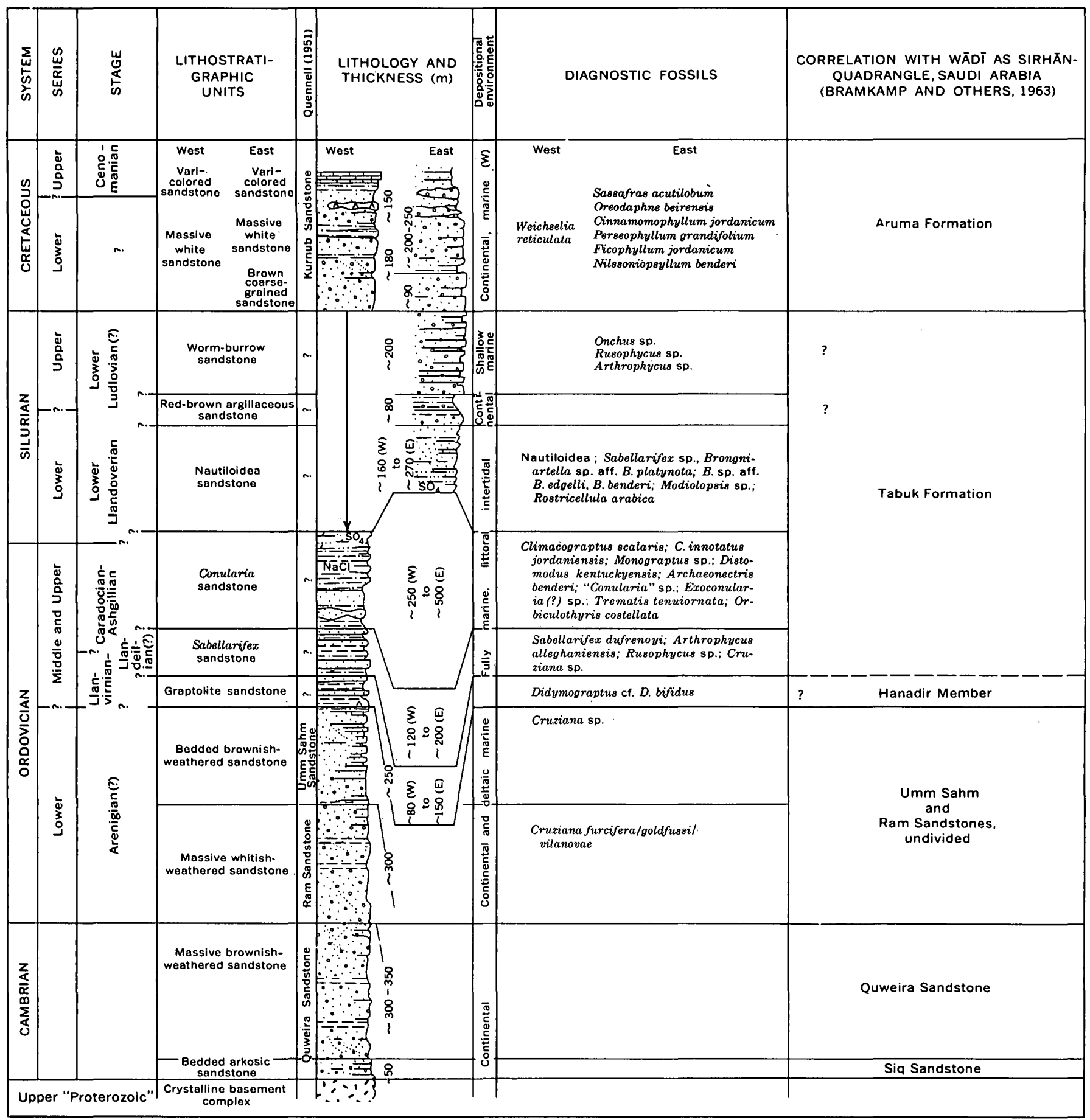

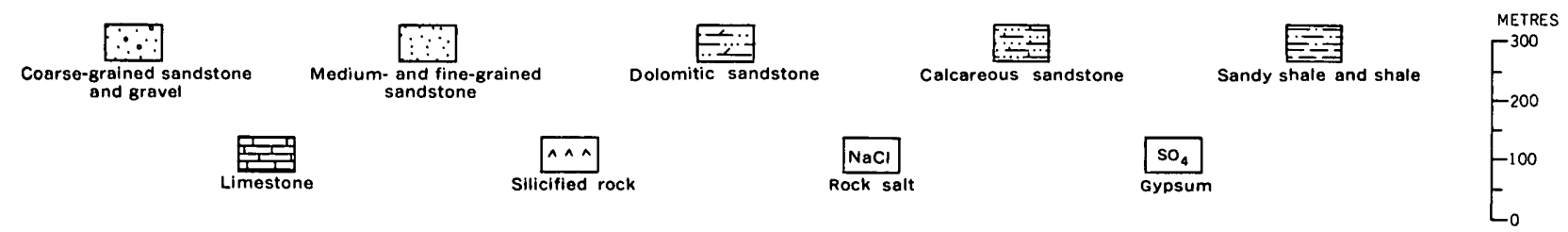

Figure 16.-Composite columnar section of Cretaceous and Paleozoic sedimentary rocks in south Jordan. 
fine-grained sandstone as much as $110 \mathrm{~m}$ thick that interfinger with, and farther south and east are replaced by, the lower part of massive brownishweathered sandstone of continental origin (fig. 3; altogether as much as $350 \mathrm{~m}$ thick; Quweira Sandstone of Quennell, 1951). To the north and west, however, the white fine-grained sandstone is gradually replaced by a marine dolomite-limestoneshale sequence (as much as $50 \mathrm{~m}$ thick), which has been known for a long time in the Dead Sea area and has yielded fossils of latest Early to Middle Cambrian age (Blanckenhorn, 1912, p. 129; Dienemann, 1915, p. 23-26; King, 1923; Richter and Richter, 1964; Picard, 1942; Wādī Nasb Limestone of Hull, 1886; and Burj Limestone Group of Quennell, 1951, and of Burdon, 1959).

The upper part of the massive brownishweathered sandstone of southern Jordan also overlies the marine Cambrian beds farther north; in the area east of the Ghawr aş Şäfi and the Dead Sea, it is gradually replaced by white bedded sandstone (as much as $220 \mathrm{~m}$ thick, Lillich, 1964, ${ }^{17}$ 1969), which also may be of marine origin and which is tentatively placed in the Cambrian (pl. 2).

Locally, Ordovician sandstone (fig. 3) crops out conformably above the Cambrian clastic rocks on the east side of Wādi al 'Arabah. In south Jordan east of the Rift province, the Ordovician sequence is more complete, because it dips gently east-northeast underneath Cretaceous strata, that rest upon Paleozoic rocks having a slight angular unconformity.

Massive whitish-weathered sandstone of Ordovician age was deposited in an alternating continental and deltaic-marine environment. The dominantly coarse grained and commonly crossbedded sandstone contains many gravel lenses and scattered quartz pebbles. The sandstone is as much as $300 \mathrm{~m}$ thick in the Khawr Ramm-Qā' Disah area in south Jordan. Some intercalated silty and micaceous shale yielded well-preserved Early Ordovician (Arenigian?) trace fossils (determined by Huckriede in Bender and Huckriede, 1963). The formation was named Ram Sandstone by Quennell (1951) who considered it to be of continental origin and of any age from Cambrian to Jurassic.

Without visible unconformity, bedded brownishweathered sandstone approximately $250 \mathrm{~m}$ thick lies above the massive whitish-weathered sandstone.

\footnotetext{
${ }^{17}$ Lillich, Wolfgang, 1964, Stratigraphical investigations on the Paleozoic and Mesozoic sandstones on the east side of the Dead Sea: German Geol. Mission to Jordan, unpub. rept., Fed. Rep. Germany Geol. Survey, Hannover.
}

It is exposed only in southern Jordan along a 10- to 15-km-wide belt that extends south-southeast from the escarpment of Ra's an Naqb into Saudi Arabia. The sandstone is poorly sorted and dominantly coarse grained in the lower part, and well sorted and dominantly medium grained in the upper 50-70 $m$ of the formation. It appears dark brown or even black, because of desert varnish; its original colors were pink, beige, gray-brown, and, in the upper part, white. It seems to have been deposited in a nearshore, tidal and in an offshore, shoals environment, and has yielded some traces of fossils (Selley, $\left.1968^{18}\right)$. The formation is classed as Lower Ordovician because it rests on top of known Lower Ordovician strata and is in turh overlain by fossiliferous sedimentary rocks of Llanvirnian Age. This formation had been named the Ümm Sahm Sandstone and assigned to the continental Nubian Sandstone Series of Paleozoic-Triassic-Jurassic age by Quennell (1951).

The Umm Sahm Sandstone is overlain, with a marked lithologic break, by varicolored hard shale, silicified red-brown fine-grained sandstone, and brown well-bedded fine-grained sandstone that alternate with friable sandy shale and siltstone; these beds aggregate approximately $80 \mathrm{~m}$ thick. The lower strata of these shallow-water marine finegrained clastic rocks contain the Llanvirnian (Middle Ordovician) index fossil Didymograptus cf. $D$. bifidus (determined by Huckriede, in Bender and Huckriede, 1963). The formation was named graptolite sandstone because it contained the first graptolites discovered in Jordan (Bender and Huckriede, 1963 , p. 25). The upper contact was established where sandstone strata full of vertical tubes of Sabellarifex overlie greenish friable shale of the graptolite sandstone. The Sabellarifex sandstone consists of dominantly fine-grained sandstone alternating with a few sandy shale beds (Bender and Huckriede, 1963, p. 252). It is approximately 120 $m$ thick where exposed west of the Hejaz Railroad. According to the fossil content of the formations below and above it, the Sabellarifex sandstone is of Middle Ordovician age (Wolfart, 1968, p. 523).

The Sabellarifex sandstone in turn is conformably overlain by marine-littoral fine-grained clastic beds, which contain more silty and fine-grained sandy shale layers than does the Sabellarifex; also, these clastic beds locally contain some gypsum and

${ }^{18}$ Selley, R. C., 1968, Sedimentology of the Nubian sandstones in the southern desert of the Hashemite Kingdom of Jordan: Jordan Nat. Res. Authority unpub. interim rept. Jordan Nat. Resources Authority, Amman, Jordan: 
rock-salt lenses about $1 \mathrm{~cm}$ thick. The lower contact of the clastic beds has been placed at the base of a 12- to 15-m-thick layer of friable greenish sandy shale above Sabellarifex-bearing sandstone. This formation was named Conularia sandstone for Exoconularia (?) sp. (Bender and Huckriede, 1963) found in the lower third. The Conularia sandstone is altogether about $250 \mathrm{~m}$ thick, as measured west and east of the Hejaz Railroad between Mahattsat Baţn al Ghūl and Al Mudawwarah. This formation has yielded many fossils described in Bender and Huckriede (1963), Huckriede (1967), Bender (1968a), and Wolfart (1968) and can be placed in the Caradocian-Ashgillian-lower Llandoverian(?).

In southern Jordan east of the Hejaz Railroad, Silurian sandstone and shale conformably overlie the Upper Ordovician. The paleontologic definition of the Ordovician-Silurian boundary is still controversial (Wolfart, 1968). For practical purposes it has been here tentatively placed where the thick marine sequence consisting of the Ordovician graptolite and Sabellarifex sandstones and the Upper Ordovician to Lower Silurian(?) Conularia sandstone is overlain by the Nautiloidea sandstone (pl. 2 ; fig. 4, 16). Alternating flaggy fine-grained sandstone and sandy shale beds characterized by many nautiloids overlie the Conularia sandstone without a major lithologic break. The Nautiloidea sandstone has yielded many fossils that have been described by Huckriede (Bender and Huckriede, 1963) and Wolfart (1968). This sandstone unit is approximately $160 \mathrm{~m}$ thick east of the Hejaz railroad. The total thickness of the whole marine sequence from the Llanvirnian (graptolite sandstone) to the lower Llandoverian (Nautiloidea sandstone) is thus approximately $560 \mathrm{~m}$. The same sequence is $1,000 \mathrm{~m}$ thick or more in Paleozoic sedimentary basins, as indicated by data from drilling operations approximately $20 \mathrm{~km}$ northeast of Al Mudawwarah, and by geoelectric and seismic-reflection surveys in the $\mathrm{Al}$ Jafr Basin.

Overlying the Nautiloidea sandstone, red-brown argillaceous sandstone approximately $80 \mathrm{~m}$ thick is exposed in southeastern Jordan (pl. 1). This formation consists of alternating red-brown coarsegrained sandstone, fine-grained sandstone, and micaceous sandy shale and was most probably deposited in a continental environment. It is placed in the Silurian because of its stratigraphic position in the sequence (fig. 16).

The red-brown argillaceous sandstone is overlain by as much as $200 \mathrm{~m}$ of well-stratified, partly crossbedded, dominantly medium- and coarse-grained gray and light-brown sandstone. Many of these strata are full of worm burrows and tracks of arthropods; some Onchus sp., which is a common fossil in the Upper Silurian, have been found (determined by Huckriede, in Bender, 1968a, p. 58) in this worm burrow sandstone.

Devonian sedimentary rocks are not exposed in Jordan, but they may be in the subsurface of the $\mathrm{Al}$ Azraq-Wādī as Sirḩān and Al Jafr Basins. Approximately 80 to $120 \mathrm{~km}$ southeast of the southeastern corner of Jordan, Lower Devonian beds crop out above the Upper Silurian worm burrow sandstone, in the Al Awi-Al Hūj Mountains in Saudi Arabia (Jauf Formation above Tawil Sandstone Member of Bramkamp and others, 1963). The Lower Devonian there consists of alternating bedded sandstone, sandy shale, fossiliferous impure limestone, algal limestone, and dolomitic limestone, all of shallow-water marine origin and totaling about $200 \mathrm{~m}$ in thickness.

Carboniferous beds also are not yet known from exposed sections in Jordan. However, a palynological study (Olexcon Internatl., Ltd., $1967^{19}$ ) of cutting samples from the Phillips Petroleum Co. SAFRA1 wildcat oil well (E. W. Pauley Oil Exploration and Phillips Petroleum Co., $1957{ }^{20}$ ) about $42 \mathrm{~km}$ east-southeast of 'Ammān revealed spores of early Westfalian A-Namurian-late Viséan Age (Bender, 1968 a, p. 213). The spores are in alternating micaceous sandstone and argillaceous sandstone, sandy shale, and impure sandy limestone. Because of the incomplete sampling in SAFRA-1, the thickness of the drilled Carboniferous section is not certainly known; it probably exceeds $200 \mathrm{~m}$.

Permian rocks are not known in exposures or in subsurface sections in Jordan. On the basis of regional stratigraphy in Syria (Weber, 1963), Israel (Gerry, 1967), and Saudi Arabia (Helal, 1964), Permian beds probably will be discovered in the subsurface of the northern and western parts of Jordan.

\section{MESOZOIC ERA}

Triassic strata are exposed on the east side of the central Jordan River valley and east of the Dead Sea. They overlie, without visible angular unconformity, the white bedded sandstone that is tentatively placed in the Cambrian (p. I16). Farther east and west of the Jordan River valley, Permian(?), Carboniferous, Devonian(?), and

10 Olexcon International, Ltd., 1967, Micronaleontology, palynology, stratigraphy, and oil source rock identification, various wells and sections: The Hague, Netherlands, Olexcon Internat., Ltd., unpub. rept. for Jordan Nat. Resources Authority.

a) See footnote 3 , on p. I2. 
Silurian-Ordovician rocks can be expected to be present between Triassic and Cambrian rocks.

On the east side of the central Dead Sea the exposed Triassic rocks consist (from top to bottom) of alternating yellow-brown fine-grained sandstone, sandy marl, and shale (approximately $65 \mathrm{~m}$ thick) ; alternating red-brown, ochre, gray and green shale, argillaceous fine-grained sandstone, and mediumand coarse-grained sandstone (approximately 50 $\mathrm{m}$ thick); and alternating red-violet sandy shale and dark-red coarse-grained sandstone (approximately $70 \mathrm{~m}$ thick). These Triassic rocks seem to have been deposited in a frequently changing continental(?) to lagoonal and littoral to neritic environment. These sedimentary rocks yield fossils of Scythian Age (Cox, 1924, 1932; Blake, 1936; Wetzel and Morton, 1959; comprehensive list in Bender, 1968a, p. 60-62). To the south, in the area of the lower course of the Wādi al Mawjib, this sequence wedges out between sandstones of Cambrian and Early Cretaceous age (Lillich in Bender, 1968a, p. 59). To the north, however, in the lower Nahr az Zarqā' (Zarqa River) the sequence contains gypsum and increases in thickness, and the marine depositional environment is more pronounced than it is on the east side of the central Dead Sea; the sequence here is more than $280 \mathrm{~m}$ thick, is of Scythian, Anisian, and Ladinian(?) Age, and includes approximately $70 \mathrm{~m}$ "Muschelkalk-facies" (Wagner, 1934). To the west across the Wãdi al "ArabahJordan Rift province, the Triassic sequence also increases in thickness to more than $1,000 \mathrm{~m}$ in Phillips Petroleum Co. oil exploration well Halhul-1, (E. W. Pauley Oil Exploration and Phillips Petroleum Co., $1958^{21}$ ) ; there the sandy facies is very thin, and limestone, dolomite, marl, and anhydrite are found instead.

Jurassic beds crop out in the areas of the lower course of the Nahr az Zarqā' (Zarqa River) to approximately $20 \mathrm{~km}$ south of it, on the east side of the Jordan River valley. Farther south, on the east side of the northern Dead Sea, Jurassic beds are absent, and Lower Cretaceous sandstone rests directly on Triassic rocks.

The exposed Jurassic strata consist of (from top to bottom) : alternating limestone and sandy marl (220(?) $\mathrm{m}$ thick), plant-fossil-bearing sandstone (as much as $70 \mathrm{~m}$ thick), and thick-bedded limestone (as much as $70 \mathrm{~m}$ thick). These rocks are of littoral to neritic origin and yield fossils of Bathonian Age (Cox, 1925; Muir-Wood, 1925;

\footnotetext{
${ }^{21}$ See footnote 3 on p. I2.
}

Wetzel and Morton, 1959 ; van den Boom and Lahloub, $1962^{22}$; comprehensive fossil list in Bender, 1968a, p. 64-67).

The Jurassic sedimentary rocks increase considerably in thickness northward from the outcrop area and westward across the Rift province to more than $2,000 \mathrm{~m}$ in the oil exploration well $\mathrm{Hal}$ hul-1 north of Hebron. There the sequence is of dominantly calcareous-marly, neritic to bathyal facies and probably represents the Aalénian, Bajocian, Bathonian, Callovian, and Oxfordian.

Quennell (1951) and Burdon (1959) classified and described the Jurassic and Triassic rocks in Jordan as the Zarqa Group.

Lower Cretaceous rocks are exposed locally in some structurally elevated areas in west Jordan, and northern Jordan east of the Rift province. They are also found along a belt that parallels the east side of the Dead Sea-Wādi Al 'Arabah section of the Rift province, and along the escarpment of Ra's an Naqb in the southeast. They are separated from older sedimentary rocks by a regional depositional hiatus (angular unconformity). Where exposed, the Lower Cretaceous rocks overlie:

1. Oxfordian (?) limestone in west Jordan ;

2. Bathonian calcareous sandstone and impure limestone on the east side of the Jordan River valley ;

3. Triassic limestone, shale, and sandstone between the northeast corner of the Dead Sea and the Wādī al Mawjib;

4. Silurian sandstone and shale in southeast Jordan;

5. Ordovician sandstone and sandy shale between Ra's an Naqb and the Hejaz Railroad in south Jordan; and

6. Cambrian and remnants of Ordovician sandstone at the east side of Wādi al 'Arabah.

West of the Jordan River-Dead Sea part of the Rift province, varicolored sandstone, argillaceous sandstone, and sandy shale and marl (more than $300 \mathrm{~m}$ thick) are of dominantly continental origin and are considered to be Neocomian (equal to the Wādi Hathira Sandstone of Shaw, 1947; or Kurnub Sandstone of Quennell, 1951). Limestone, sandy limestone, and marl of marine origin and of Aptian to Albian Age form the upper part (more than 80 $m$ thick) of the Lower Cretaceous (Blake, 1936; Wetzel and Morton, 1959). These marine beds increase in thickness toward the western parts of Jordan (Phillips Petroleum Co. oil exploration well

22 Boom, Günter van den, and Lahloub, Mahmoud, 1962, The iron-ore deposit "Warda" in the southern Ajlun district: German Geol. Mission in Jordan, unpub. rept., Fed. Rep. Germany Geol. Survey, Hannover. 
Ramallah-1, E. W. Pauley Oil Exploration and Phillips Petroleum Co., $1958{ }^{23}$ ); they decrease in thickness toward the east across the Jordan River valley. There, only wedges of marine calcareous sandstone (together about $40 \mathrm{~m}$ thick) of AptianAlbian Age (Wetzel and Morton, 1959, p. 138) crop out in the upper part of a section of approximately $170 \mathrm{~m}$ of varicolored, coarse-, medium-, and fine-grained sandstone, sandy shale, and sandy marl that commonly contain plant fossils of Neocomian Age (Edwards, 1929).

South from the Dead Sea and southeast along the escarpment of Ra's an Naqb, two units can be distinguished in the Lower Cretaceous sequence-a lower unit of massive white sandstone (as much as $180 \mathrm{~m}$ thick), and an upper unit of varicolored sandstone (as much as $150 \mathrm{~m}$ thick). Both lithostratigraphic units contain Early Cretaceous plant fragments and are apparently of continental origin. Only the uppermost part of the varicolored sandstone, which is more marly and shaly, shows some marine influence (agglutinate Foraminifera, fish teeth) in the Ra's an Naqb area.

In southeast Jordan, east of the Hejaz Railroad, the massive white sandstone is gradually replaced by brown coarse-grained sandstone (as much as $\mathbf{9 0}$ $m$ thick), whereas the varicolored sandstone facies diachronously "migrates" from the Lower Cretaceous into successively younger time-stratigraphic units (Cenomanian, Turonian, Santonian) as one approaches the Nubo-Arabian Shield to the southeast (Bender and Mädler, 1969).

Upper Cretaceous strata underlie most of the Highlands West of the Rift and most of the northern part of the Mountain Ridge provinces, and they cover almost the entire Central Plateau (pl. 1). The beginning of the Late Cretaceous sedimentation in west, north, and central Jordan is marked by a marine calcareous facies, whereas in southeast Jordan, deposition of sandy sediment continued in a continental environment.

Alternating limestone, dolomitic limestone, marl, shale, locally gypsum, and some chert were deposited on top of the Lower Cretaceous varicolored sandstone. This unit is the nodular limestone member (definitions of Upper Cretaceous lithostratigraphic members given by Bender, 1968a, p. 72-82), which correlates with the lower part of Quennell's (1951) Ajlun Group. It may exceed $450 \mathrm{~m}$ in thickness in west Jordan, close to the east side of the rift; in the lower course of the Wādi al Mawjib it was

20 See footnote 8 on p. I2. measured as approximately $300 \mathrm{~m}$, and from there to the south and southeast the thickness decreases to less than $70 \mathrm{~m}$ at Ra's an Naqb. On the basis of its abundant fossils, the nodular limestone is assigned to the Cenomanian (Blanckenhorn, 1914). It is succeeded by the echinoid limestone member, which consists of alternating thick- and thin-bedded limestone, dolomitic limestone, marl, and some shale, locally with some gypsum layers; it is equivalent to the middle and upper parts of Quennell's (1951) Ajlun Group. The echinoid limestone member is approximately $210 \mathrm{~m}$ thick in the area of the $\mathrm{Nahr}$ az Zarqa'' (Zarqa River); the thickness may increase to the west and decreases to the south and to the southeast. The upper third shows an increasing sand content south and southeast from the Wādī al Mawjib area. The lower two-thirds of the echinoid limestone member is of Cenomanian Age, its upper third-including its lateral facies equivalent, the sandy limestone member (as much as $110 \mathrm{~m}$ thick), south of Wãdi al Mawjib-is placed in the Turonian and Santonian.

In north Jordan, the massive limestone member of Santonian Age (as much as $60 \mathrm{~m}$ thick) was deposited on top of the echinoid limestone member and is equivalent to the uppermost part of Quennell's (1951) Ajlun Group.

South of 'Ammān, the massive limestone member gradually wedges out, and the succeeding silicified limestone member of Campanian Age directly overlies the echinoid limestone member, or its facies equivalent, the sandy limestone member. Thinbedded silicified limestone, chert layers, thin moreor-less silicified phosphorite, and thin limestone beds form this mappable lithostratigraphic member (silicified limestone member). It is present everywhere in the country except in the extreme southeast, where it wedges out or, together with the underlying Upper Cretaceous rock units, is replaced by the continental varicolored sandstone. The silicified limestone member is approximately $135 \mathrm{~m}$ thick in the Wādi al Mawjib area, but decreases to the west across the Rift province, and $12 \mathrm{~km}$ east of Al Khalil (Hebron) it is 20-30 m thick; to the east and to the south at Mahattat al Hasā and Al Qațānah it is $40-70 \mathrm{~m}$ thick, and at Zakimat al Hुasã it is less than $20 \mathrm{~m}$ thick.

Above the silicified limestone member, the phosphorite member of Campanian and Maestrichtian Age consists of alternating thin-bedded limestone, more-or-less silicified or calcified phosphorite layers, thick-bedded and crossbedded oyster lumachelles, and lenses and layers of minable phosphate. The 
phosphorite member is approximately $90 \mathrm{~m}$ thick close to the Rift province in the Wãdi at Mawjib area, and decreases in thickness to the east, to the south, and to the west across the rift.

Both the silicified limestone member and the phosphorite member form the lower part of Quennell's (1951) Belqa Group.

Soft chalk, marl, marly limestone, and locally massive and crystalline limestone (so-called marble) rest (with a marked lithologic break) on top of the phosphorite member. This chalk-marl member, which is equivalent to the upper part of Quennell's (1951) Belqa Group, ranges in thickness from about $20 \mathrm{~m}$ in southeast Jordan to more than $450 \mathrm{~m}$ as drilled in the Al Jafr Basin. The thick sequence is restricted to basins that strike northwest. Locally in these basins an euxinic facies of bituminous marly limestone exceeds $200 \mathrm{~m}$ in thickness, as in the Nahr al Yarmūk (Yarmuk River) area in north Jordan. On the basis of microfossil evidence, the chalk-marl member represents the upper Maestrichtian, Danian, and lower Paleocene, and in addition upper Paleocene and lower Eocene in the sedimentary basins that contain thick deposits of the chalk-marl member.

\section{MESOZOIC VOLCANIC ROCKS}

West of the Jordan River, in the Wādī al Māliḩ approximately $9 \mathrm{~km}$ east of the village of Tübäs, deeply weathered mafic to intermediate exuptive rocks (phonolites, according to Ionides and Blake, 1939) are exposed. They intrude Middle Jurassic limestones, and are, together with tuffs and agglomerates, covered by Lower Cretaceous sandstone. Similar, but smaller outcrops are reported from Wādi al Fāri'ah and near Lūhuf Jadìr west of the Jordan River (Rofe \& Raffety Consultant Engineers, $1965^{24}$ ).

Silicic dikes and sills in the Triassic limestones in the area of Wādi Hisbān at the northeast corner of the Dead Sea are mentioned by Quennell (1951, p. 104). At 'Ayn Mūsã of the same area, Wetzel and Morton (1959, p. 124) found trachyte sills and lenses of volcanic ash in the marly sandy beds below and above the Triassic (Muschelkalk) limestones. The age of the dolerite dikes in Wādi al Karak and at several places at the central east side of Wādi al 'Arabah is yet uncertain; they may have formed during the widespread Pleistocene basalt volcanism.

\section{CENOZOIC ERA}

Marine sedimentation during the Late Cretaceous continued without a major lithologic break into the

${ }^{24}$ See footnote 14 on $p$. I2.
Tertiary. Sedimentary rocks of Paleocene and Eocene age cover extensive areas in north, northeast, and east-central Jordan; parts west of the Jordan River; and small stretches along the east side of the Wādi al 'Arabah part of the Rift province (pl. 1).

Massive chalky limestone, alternating thinbedded limestone and chert layers, and local nummulitic limestone that range in age from early Paleocene to middle Eocene overlie the chalk-marl member. For regional mapping purposes, these sedimentary rocks were described and classified as the chert-limestone member (Bender, 1968a, p. 82-87) ; it is in part the time equivalent of the upper part of the chalk-marl member that was still being deposited in sedimentary basins where marly and bituminous sedimentation continued into the Eocene. The chert-limestone member is as much as $180 \mathrm{~m}$ thick in the Al Azraq-Wādī as Sirḩān sedimentary basin; it decreases in thickness toward south Jordan.

Above the chert-limestone member are the carcharodon marls (more than $50 \mathrm{~m}$ thick) and the limestones and cherts of Thuleithuwat (more than $30 \mathrm{~m}$ thick) (pl. 2); on the basis of microfossil evidence determined by Wilhelm Koch (in Bender, 1968 a, p. 85) these units are of middle Eocene age. They are partly the time equivalent of the barite marls and bituminous marls of Dahikiya (more than $25 \mathrm{~m}$ thick), of which the upper part extends into the upper Eocene on the basis of microfossils determined by Koch (in Bender, 1968a, p. 85). These beds crop out locally as erosion remnants in the eastern parts of the Central Plateau; they are probably much thicker in the Al Azraq-Wādī as Sirḩān sedimentary basin.

Oligocene-Miocene strata indicate distinct changes in the depositional environment, which since the Cenomanian had remained marine calcareous over most of Jordan. Glauconitic sandstone, limestone, and sandstone of Oligocene-Miocene age (more than $70 \mathrm{~m}$ thick) unconformably overlie upper Eocene rocks in the Al Azraq-Fayḑat aḑ Ḑāhikīyah area, and crop out locally east of the Plateau Basalts in northeast Jordan.

Glauconitic, partly sandy limestone and marl, more than $40 \mathrm{~m}$ thick, are exposed in Wàdi at Tayyibah on the east side of the northern Jordan River valley. They unconformably overlie middle Eocene rocks and are, according to Wetzel and Morton $(1959$, p. 167), of Oligocene age. In the village of Shūnat Nimrin in the same area, approximately $40 \mathrm{~m}$ of glauconitic and in part sandy limestone is exposed; it probably 
is of Oligocene-Miocene age (Wiesemann and $\mathrm{Ab}$ dullatif, $1963{ }^{25}$ ).

The lower syntectonic conglomerate unconformably overlies different units of the Upper Cretaceous and the lower Tertiary; it crops out only along the east side of Wādi al 'Arabah and apparently indicates the first major taphrogenic movements of the Jordan rift zone. The lower syntectonic conglomerate consists of alternating conglomerate, sandstone, marl, shale, gypsiferous shale, and some flaky limestone intercalations that total $280 \mathrm{~m}$ in thickness in the type-section area approximately $10 \mathrm{~km}$ north-northeast of Ash Shawbak (Bender, 1968b, p. 186-188). They contain fossil fresh-water fishes (Cichlidae) and plants (certain Characeae). The plant fossils are thus far known to be restricted to the Rupelian and Tortonian in Europe (determined by Karl Mädler, in Bender, 1968b, p. 188). The lower syntectonic conglomerate is also locally exposed within the Rift province-for example, at Gharandal in the central part and at Wàdi Dabl in the northern part of the east side of Wādi al 'Arabah. Here, marine influence on the depositional environment is shown in sandy marl layers in the upper part of the lower syntectonic conglomerate; these marl layers contain Ammonica aff. $A$. beccarii (Linné), indicative of earliest Miocene (determined by Koch, in Bender, 1968a, p. 88).

The upper syntectonic conglomerate (more than $100 \mathrm{~m}$ thick), deposited on an angular unconformity, is mainly a thick-bedded coarse-grained conglomerate that has a sandy calcareous matrix, and overlies the lower syntectonic conglomerate. The upper syntectonic conglomerate is also restricted to the east side of Wãdi al 'Arabah; it is of continental origin and probably of late Neogene age.

The upper syntectonic conglomerate may be the time equivalent of the sandy marls and conglomerates (more than $200 \mathrm{~m}$ thick) of Adh Dhirā' east of the Al Lisān Peninsula in the Dead Sea (Wetzel and Morton, 1959, p. 169), and of the marine oolitic limestones (more than $40 \mathrm{~m}$ thick) from Jabal al Khurayj in the central Wādi al 'Arabah (Bender, 1968a, p. 91).

Also of marine origin and of Miocene age are the sandstone and sandy marl (as much as $40 \mathrm{~m}$ thick) of Al Azraq-Fayd̦at ad̦ Dुähikikiyah west and

\footnotetext{
25 Wiesemann, Gerd, and Abdullatif, A., 1963, Geology of the Yarmuk area, north Jordan: German Geol. Mission in Jordan, unpub. rept. Fed. Rep. Germany Geol. Survey, Hannover.
}

east of the Plateau Basalt (Baker and Harza Engineering Co., $1968{ }^{26}$; Heimbach, 1970).

Restricted to the central and structurally deepest zone of the Rift province are the evaporites of $\mathrm{Al}$ Lisān. They were not penetrated in the 3,560-m-deep oil exploration well El Lisan-1; according to a seismic-reflection survey by ARGAS in $1968^{27}$, a thickness of approximately $4,000 \mathrm{~m}$ can be assumed for this unit. Thus, the evaporites are a major part of the total post-Proterozoic sedimentary column which is on the order of $10,000 \mathrm{~m}$ thick beneath the Al Lisān Peninsula. The evaporites consist mainly of halite and a few thin carnallite layers plus some anhydrite, shale, and marl. The shale and marl increase rapidly in thickness toward the east edge of the rift valley, but more gradually toward the south. According to the seismic-reflection survey, it seems that in the southern Ghawr aş Şäfi area, approximately $20 \mathrm{~km}$ south of the Dead Sea, the salt mass is almost completely replaced by a well-bedded sequence that probably consists of shale and marl. The salt probably represents a "salt cushion" (that is, a gentle doming of the upper surface of the salt bed), which was greatly disturbed at its eastern flank by taphrogenic structural movement, rather than a diapiric salt dome. Palynological studies have revealed that the evaporites are of late Miocene(?) to Pliocene age, and may in part be earliest Pleistocene (determined by Mädler, in Bender, 1968a, p. 90).

Along the east side of the Jordan River valley, well-cemented coarse-grained clastic rocks alternating with travertines locally overlie older rock sequences unconformably. These clastic rocks, the Shagur Formation (more than $100 \mathrm{~m}$ thick), have been strongly deformed by structural movements. They are of continental origin and contain gastropods and ostracodes of late Pliocene to early Pleistocene age (Huckriede, 1966), and thus represent the oldest Quaternary rocks in Jordan.

A sequence of alternating conglomerate, sandstone, marl, shale, and fossil red soil (more than $350 \mathrm{~m}$ thick) equivalent to the Series of Grain Sabt (Ionides and Blake, 1939) is exposed in the central Jordan River valley. These rocks are also structurally deformed, but to a lesser degree than is the Shagur Formation. On the basis of rare fossils, the

\footnotetext{
${ }^{20}$ Baker, M., and Harza Engineering Co., 1958, The Princess Alia project- Definite plan report (Azraq), land resources: Baker and Harza Engineering Co., unpub. rept. for the Jordan Government.

${ }^{27}$ Arabian Geophysical and Surveying Co. (ARGAS), 1968, Seismic report El Lisan-Ghor Safi: ARGAS, unpub. rept., Jordan Nat. Resources Authority, Amman, Jordan.
} 
Series of Grain Sabt is tentatively placed in the lower Pleistocene (equivalent to the Ghor el Katar Series of Huckriede, 1966).

Pebble tools of the Oldowan type were discovered by Huckriede (1966) in the gravels of Abū Habil (more than $10 \mathrm{~m}$ thick) on the east side of the central Jordan River valley; Huckriede classed these gravels as middle Pleistocene. He also found early Paleolithic chert implements in the gravels of Kufrinjah, approximately $60 \mathrm{~km}$ north of the Dead Sea on the east side of the Jordan River valley.

The Lisan Formation unconformably overlies all older rock sequences in the Rift province. It consists of a lower fossiliferous member, mainly shale and marl (approximately $30 \mathrm{~m}$ exposed), and an upper member of varve-bedded marl and shale containing some gypsum and native sulfur (approximately $60 \mathrm{~m}$ exposed). The Lisan Formation is of late Pleistocene age and was deposited in a fluctuating oligohaline and miohaline lacustrine environment (Huckriede, 1966). Vita-Finzi (1964) reported upper Pleistocene chert implements from the upper part of the Lisan Formation in the Jordan River valley. At the period of its largest extension, the Lisan Lake covered the entire rift valley from Lake Tiberias to approximately $80 \mathrm{~km}$ south of the Dead Sea, a lake some 280 to $300 \mathrm{~km}$ long.

Along the margin of the Rift province, the Lisan Formation is intercalated with, or locally replaced by coarse clastic and sandy deposits derived from the elevated areas bordering the rift valley. At other localities close to the shores of the ancient Lisan Lake, a calcareous pseudo-oolitic facies of the Lisan Formation, more than $10 \mathrm{~m}$ thick, was depositedfor example, at Khirbat as Samrā' north of Arīhā (Jericho).

Outside the rift valley, fluviatile-lacustrine sediments were deposited in barred basins and depressions during the Pleistocene-for example, $1 \mathrm{~km}$ east-southeast of Gharandal, west of Mabattat al Hुasā and in the Al Jafr and Al Azraq-Wādi as Sirhān Basins. Fluviatile gravels cover extensive areas of the eastern slopes of the Mountain Ridge province and also of the adjacent Central Plateau.

River and wadi gravels, loesslike sediments and aeolian sands, mantle rocks, landslide masses, talus fans, pelitic sediments in mud flats, calcareous sinter, and caliche form the major constituents of the Holocene deposits.

\section{CENOZOIC VOLCANIC ROCKS}

During the late Neogene and Pleistocene, basaltic volcanism was widespread in Jordan in the following areas: West of the Jordan River, within the Rift province; along the Mountain Ridge province, along the northwest-striking fracture zones in central and south Jordan; and within the Plateau Basalt province.

West of the Jordan River, basalt is rare, and of lesser areal extent than in Jordan east of the rift. A lava flow covering about $1 \mathrm{~km}^{2}$ overlies Eocene limestone approximately $9 \mathrm{~km}$ east of Janin. Even smaller extrusions, probably connected with northwest- and east-striking fault zones, were found at 'Ānin (approximately $14 \mathrm{~km}$ west-northwest of Janin), at Rāfāt (approximately $25 \mathrm{~km}$ southwest of Nāblus), and at Sālim.

Within the rift zone, many rather small areas of basalt and tuff were mapped (Bender and others, 1968, Amman sheet) between the Dead Sea and Lake Tiberias; they are absent south of Al Lisān. The basalt flow of Ghawr al Katār approximately $26.5 \mathrm{~km}$ north of the Dead Sea unconformably overlies the Series of Grain Sabt (lower Pleistocene) and is in turn overlain by the Lisan Formation. (upper Pleistocene). The basalt flows near the east shore of the northern Dead Sea overlie fluviatile gravels that contain implements of the Acheulian. A middle Pleistocene age is therefore assigned to the activity of these volcanoes.

The basaltic rocks along the Mountain Ridge province are restricted to an area approximately 20 $\mathrm{km}$ wide and $110 \mathrm{~km}$ long between Jabal 'Unayzah in the south and Wādi al Mawjib in the north. The basalt flows on the upper south side of the Wādi al Mawjib valley overlie fossil soils and wadi gravels; the basalt lava of Jabal al Qirānah about $5 \mathrm{~km}$ northwest of Mahattat Jurf ad Darāwish overlies fluviatile gravels of middle Pleistocene age, which yielded many Acheulian implements (Bender, 1968a, p. 99, 105).

Along the northwest-striking Al Karak-Wādì al Fayhā fracture zone, which extends across the entire Central Plateau for more than $300 \mathrm{~km}$, several isolated basalt flows and basalt and dolerite dikes were observed. The basalts contain many inclusions of the calcareous or siliceous country rock that show traces of superficial melting. The flows also have been found overlying fluviatile gravels of middle Pleistocene age. In southern Jordan between $\mathrm{Al}$ Quwayrah and Al Mudawwarah, another northweststriking fracture zone, mainly tension fissures of great vertical extent along which basalt dikes have 
intruded, extends for about $70 \mathrm{~km}$ through lower Paleozoic sandstone. These basalts contain inclusions of Upper Cretaceous limestone that apparently covered this area at the time the fractures were formed.

The Plateau Basalts of Djebel ed Drouz and Wādī Haurān cover an area of about $45,000 \mathrm{~km}^{2}$ (in Jordan about $11,000 \mathrm{~km}^{2}$ ), and extend from the southern rim of the Damascus Basin in Syria southward into northeast Jordan to the northern rim of the Al Azraq depression. The flows continue for about $210 \mathrm{~km}$ southeastward into Saudi Arabia ( $\mathrm{Al}$ Hुarrah) along the east side of the Al Azraq-Wãdi as Sirhān Basin.

An enormous amount of extrusive rock erupted from many fissures; many vents are still visible as long rows of low cones. Basalt and some tuff also were extruded from clusters of isolated eruption cones. Six different phases of major emissions can be distinguished (van den Boom and Suwwan, 1966, p. 10-20 ${ }^{28}$; Bender and others, 1968, El Azraq and $\mathrm{H}-4$ sheets).

The basalt flows of the lower three phases are only known from wells drilled for ground water in the Wādi az Zुulayl area northeast of 'Ammān (Hunting Tech. Services, Ltd., $1965{ }^{29}$ ). These flows are, altogether, as much as $150 \mathrm{~m}$ thick in this area and are separated from each other by approximately $5 \mathrm{~m}$ of fossil soils, red clays, and fossil weathered basalt surfaces. The uppermost of these three flows is in turn overlain by soils 6 to $20 \mathrm{~m}$ thick that are locally covered by a fourth flow which was drilled to a depth of $60 \mathrm{~m}$ in Wādi az Zुulayl. This fourth flow is exposed between oil pump stations H-5 and $\mathrm{H}-4$ and in the area east of Faydुat aḑ Dāhikikiyah; it covers a rather flat surface of older flows or middle and upper Eocene limestones and is locally covered by sandstone, calcareous sandstone, and sandy marl of Miocene age. The eruption of lava flows 1 to 4 can be therefore placed in a time interval which at the earliest started in the late Eocene and at the latest ended in the Miocene.

A fifth flow, which is as much as $25 \mathrm{~m}$ thick where exposed but may be much thicker toward the center of the eruptions, is the most extensive flow of the northeast Jordan plateau basalts. This fifth flow covers older flows and Paleogene and Miocene sediments; it can be correlated with the basalts on the limestone plateau of the Nahr al Yarmūk (Yarmuk River) area and has undergone late Pleisto-

\footnotetext{
ga Boom, Günter van den, and Suwwan, O., 1966, Report on geological and petrological studies of the plateau basalts in northeast Jordan: German Geol. Mission in Jordan, unpub. rept. Fed. Rep. Germany Geol. Survey, Hannover, $42 \mathrm{p}$.
}

so See footnote 11 on $p$. I2. cene erasion. The main tuff eruptions started after the extrusion of lava flow 5 .

The basalts of the sixth extrusive phase form north-trending flows many kilometers long; as exposed, they are as much as $30 \mathrm{~m}$ thick and their surfaces do not show any evidence of weathering. They most probably correlate with the basalts that flowed down the Nahr al Yarmūk (Yarmuk River) valley to the west where they overlie Pleistocene fluviatile gravels and fossil landslides. On the basis of archaeological evidence, Picard (1965, p. 359) placed the basalts of the Nahr al Yarmūk (Yarmuk River) valley in the middle Pleistocene. The. long rows of low basalt cones, which apparently are fissure effusions, also are part of the sixth eruption phase, because they cross the flows of the fourth and fifth phases. These rows strike east-southeast (azimuth $110^{\circ}-130^{\circ}$ ) and were mapped over distances of $90 \mathrm{~km}$ (Bender and others, 1968, El Azraq sheet).

The latest eruptions may have continued into historical times, as for example, in some places in the Djebel ed Drouz area in Syria (de Vries and Barendsen, 1954; Burdon, 1959, p. 47).

\section{STRUCTURE}

Five major structural provinces may be distinguished according to their structural evolution, types of deformation, and pattern:

1. Wādī al 'Arabah-Jordan rift,

2. Nubo-Arabian Shield in southern Jordan,

3. Block faults in central and southeastern Jordan,

4. Upwarping, tilting, and block faulting in northern Jordan, and

5. Anticlinorium, upwarping, and block faulting west of the Jordan River.

\section{WĀDİ AL 'ARABAH-JORDAN RIFT}

The Wãdĩ al 'Arabah-Jordan rift forms a section, about $360 \mathrm{~km}$ long, of the East African-North Syrian fault system, which is recognizable over a distance of $6,000 \mathrm{~km}$. The Wādi al 'Arabah-Jordan rift strikes $\mathrm{N} .15^{\circ} \mathrm{E}$. from the Gulf of Aqaba to the Dead Sea to form the south graben, approximately $200 \mathrm{~km}$ long, and turns from there almost due north to Lake Tiberias to form the north graben, approximately $160 \mathrm{~km}$ long. The rift separates the Palestine block in the west from the Transjordan block in the east. The width of the graben floor ranges from $5 \mathrm{~km}$ to $20 \mathrm{~km}$; most of it is covered by Holocene and Pleistocene fluvial, aeolian, and lacustrine sediments. The southern part of the 
Transjordan block regionally dips more steeply northward than does the Palestine block, but the sedimentary column on the northern Palestine block is thicker than that on the northern Transjordan block; therefore, the surface structural position of the Cretaceous-Tertiary sedimentary sequences gradually attains the same level on both sides of the rift valley between the Dead Sea and Lake Tiberias.

The Precambrian structural pattern and the Precambrian joint and dike system as exposed on the east side of the south graben suggest that a structural zone of the weakness (geosuture) or major hinge line already existed here at the end of the Precambrian. Additional evidence is the morphology of the surface of the Precambrian basement complex; this surface is a peneplain some distance east of the south graben, but it is a very irregular surface covered by coarse conglomerates of Early Cambrian age on both sides of the southern part of the present rift valley. (For details on the age and evolution of the Jordan rift, see Bender, 1968b.) Continued tectonic activity along the old zone of weakness is indicated by late Proterozoic to Cambrian quartz porphyry volcanism in the southern Wādi al 'Arabah. Moreover, the presence of a hinge line, or a major paleogeographic divide, is demonstrated by the disposition of the Cambrian sedimentary facies. These facies relations suggest the existence of an elevated Transjordan block east of the southern part of the hinge line which received continental sediments, and a structurally lower Palestine block west of it which contains marine intercalations of Cambrian Age.

Thickness and facies changes in Triassic, Jurassic, Cretaceous, and lower Tertiary sedimentary rocks across the present rift valley indicate the continued mobility of the geosuture.

The taphrogenic structural movements that initiated the formation of the present graben apparently occurred along this preexisting zone of weakness (geosuture) and started during the late Eocene(?)Oligocene. In the late Oligocene-Miocene, the Transjordan block east of the south graben was structurally elevated and subjected to continental erosion and, locally, to continental deposition (lower and upper syntectonic conglomerates at the east shoulder of the south graben; p. I21). In the graben area itself, marine beds were deposited during the Oligocene and Neogene. The thick evaporite series of late Miocene(?)-Pliocene age in the Dead Sea area demonstrates the gradual decrease and termination of a marine deposition in this part of the graben. Renewed major taphrogenic movements started in the Pliocene-Pleistocene. These movements continued during several intra-Pleistocene phases and reached another maximum at the time of the wide-spread basalt volcanism of the middle Pleistocene. Further structural movements, though of small scale, are recorded in the upper Pleistocene unconsolidated sediments of the graben.

The post-Proterozoic structural movements in the rift zone, in particular those forming the graben (taphrogeny) since the Oligocene, were of dip-slip type. Only local minor movements of tangential compression and lateral displacement have been observed. Clear evidence of major strike-slip displacements along the rift on the order of $70 \mathrm{~km}$ to more than $100 \mathrm{~km}$ (Quennell, 1956; Freund, 1965), or evidence of a ramp valley due to east-west compression (Willis, 1928), was not found during geologic mapping by the author.

\section{NUBO-ARABIAN SHIELD IN SOUTHERN JORDAN}

The area bordering the northern Gulf of Aqaba, southern Wādi al 'Arabah, and the adjacent area to the east are considered to represent a northern part of the Nubo-Arabian Shield. The shield plunges regionally from there to the north and northeast. As in the southern Negev to the west (de Sitter, 1962), the structural features in this part of south Jordan indicate its cratonic character.

On the east side of Wādi al 'Arabah, southweststriking graben structures have been mapped where the upper Proterozoic Saramuj Conglomerates and the Slate-Graywacke Series (p. I13) were preserved from erosion prior to Early Cambrian deposition (Bender and others, 1968, Aqaba-Ma'an sheet). Epeirogenic movements affected the Paleozoic strata east of the southern part of Wādi al 'Arabah, resulting in the regional gentle dip of these strata to the north-northeast. The Paleozoic formations were in part eroded before the deposition of Lower Cretaceous clastic rocks. Therefore, from west to east in south Jordan, the Lower Cretaceous rocks overlie, with angular unconformity, progressively younger Paleozoic rock units that range from Cambrian in the west to Upper Silurian in the east.

Taphrogenic movements in the rift area strongly affected the area bordering the rift, chiefly along northwest-, north-, and north-northeast-striking normal faults, antithetic and synthetic fault systems, and narrow long grabens and horsts paralleling the rift.

Approximately northwest-striking tension joints and faults, of little vertical displacement but of con- 
siderable length, were traced in south Jordan. The fissures are locally filled by Pleistocene basalts.

\section{BLOCK FAULTS IN CENTRAL AND SOUTHEASTERN JORDAN}

Blocks faults in central and southeastern Jordan are characterized by broad epeirogenic swells and basins which dominantly strike northwest and westnorthwest: The Al Jafr Basin, Bāyir-Kilwah Swell, and Al Azraq-Wādì as Sirḩān Basin (pl. 3). A pattern of approximately northwest-, approximately north-northeast-, and east-striking normal faults and flexures of minor displacements form in part small horsts and grabens. The northwest-striking fault systems are very long; the Al Karak-Wādi al Faybā fault system, for example, is more than $300 \mathrm{~km}$ long and apparently is caused by deep tensional forces. In many places, Pleistocene basalts intrude this fault zone. A few small anticlinelike uplifts in central and southeastern Jordan can only be explained as caused by tangential compression (for example, Jabal at Ţāhūnah, approximately $8 \mathrm{~km}$ northwest of $\mathrm{Ma}(a \bar{n})$.

\section{UPWARPING, TILTING, AND BLOCK FAULTING IN NORTHERN JORDAN}

In Jordan east of the rift valley between lat $31^{\circ} 30^{\prime}$ and $31^{\circ} 50^{\prime} \mathrm{N}$., the pattern of dominant block faults characteristic of central and southeast Jordan gradually changes northward into another structural province where tilting becomes a common feature with faulting. This region is called the province of upwarping, tilting, and block faulting. The structures in this area are thought to have been caused by the general change in rock types, the increase in thickness, and correspondingly greater weight of the sedimentary sequence from south to north and northwest; the relatively thin and dominantly competent beds in the south reacted to structural stresses by fracturing and faulting, whereas the thicker and more incompetent beds in the north reacted to the same stresses by arching, tilting, and flexuring. Examples are:

1. The flat broad northwest-striking anticlinal trend of Jabal as Safrā', approximately $42 \mathrm{~km}$ east-southeast of 'Ammān,

2. The flat broad upwarp of of 'Ajlūn, about $45 \mathrm{~km}$ north-northwest of 'Ammān, which strikes north-northeast for about $25 \mathrm{~km}$ and is faulted mainly in its crestal area, and

3. The uplift of Suwaylih approximately $15 \mathrm{~km}$ northwest of 'Ammän, which consists of a tilted block that extends southwest for about $12 \mathrm{~km}$. This block rises gently from southeast to northwest and becomes approximately 4 $\mathrm{km}$ wide before it steeply dips northwest along a southwest-striking flexure accentuated by faults.

ANTICLINORIUM, UPWARPING, AND BLOCK FAULTING WEST OF THE JORDAN RIVER

The anticlinorium, upwarping, and block faulting west of the Jordan River are part of a broad arched region that extends to the northern Negev in the south and to Galilaea in the north. The region in general gently dips westward to the Mediterranean Sea, but dips more steeply to the east, before it is abruptly limited by the Jordan rift.

The upwarps of the region are the Negev upwarp in the south, the upwarp west of the Jordan River in the center, and the Galilaean upwarp in the north. Each is a part of the anticlinorium and is subdivided into anticlines and synclines and into tilted blocks commonly limited by flexures. In the Negev upwarp and in the southern part of the upwarp west of the Jordan River, these structures strike mostly northeast, but in the Quseife, Al Khalil (Hebron), Rāmallah, and the Al Buqay'ah anticlines in the central part of the upwarp west of the Jordan River, a north-northeast-striking structural trend becomes dominant. A northwestand west-northwest-striking fault system in the northern part of the upwarp west of the Jordan River cuts these structural trends, but their northnortheast continuation can be traced in the northernmost part of the upwarp and in the Galilaean upwarp.

\section{ECONOMIC GEOLOGY so AQUIFERS}

The following major aquifer systems may be distinguished in Jordan:

1. Lower Paleozoic sandstones are important only in the southern and southeastern parts of the country; they receive little direct recharge; ground-water movement is generally east or northeastward.

2. Carboniferous(?), Triassic, and Jurassic sandstones underlie the Cretaceous sandy and calcareous sequences in northern Jordan; depth to these aquifers is more than $400 \mathrm{~m}$ in most areas that require ground-water utilization.

3. Cretaceous sandstones may be hydraulically connected with the Jurassic-Triassic systems in the northern part of the country. Owing to intercalated impermeable strata of variable thickness and extent, several aquifers may be

3u See Note, p. iv. 
present within the Cretaceous sandstones at a particular locality. Generally the Cretaceous sandstones are of limited value for economic utilization of ground water because of considerable drilling depths, commonly low permeability, and poor water quality.

4. Cenomanian and Turonian limestones form locally important aquifers mainly in northern Jordan, where they are directly recharged from rainfall on outcrops along the Mountain Ridge east of the Rift.

5. Campanian and Maestrichtian intercalated limestone, silicified limestone, chert, and phosphorite form the most important and extensive aquifer system in Jordan. These Upper Cretaceous rocks crop out in the relatively high rainfall zones along the mountain ridges and highlands east and west of the rift valley, and in large areas they are at depths that can be economically drilled beneath a cover of younger sediments. Ground-water movement generally follows the regional dip away from the rift valley-eastward from the mountain ridges east of the rift, and westward from the highlands west of the rift. However, many of the larger tributaries and side wadis of the Jordan River valley and the Dead Sea cut back into these aquifers and even into deeper aquifers and cause the ground-water to flow toward the rift valley.

An aquifer of local importance is formed by the lower Tertiary chert-limestone member, mainly in the central parts of the $\mathrm{Al}$ Jafr and Al AzraqWādī as Sirḩān Basins.

The chert-limestone member may be hydraulically connected with aquifers in the Neogene sandstone and sandy marl of Al Azraq and with aquifers in the extensive basalt rock sequence of NeogeneQuaternary age north of Al Azraq. Within the rift valley, aquifer systems of local importance are formed by the upper Neogene, upper syntectonic conglomerate, the sands in the Series of Grain Sabt of early Pleistocene age, the coarse clastic intercalations in the Lisan Formation (upper Pleistocene), and the more recent alluvial clastic deposits.

Extensive ground-water investigations were made in Jordan during 1964 through 1969, in particular, by the Food and Agriculture Organization of the United Nations (Parker, 1969; Lloyd, 1969).

OIL AND GAS, BITUMINOUS ROCKS, AND ASPHALT ${ }^{31}$

For several decades the zone of sedimentary troughs within the unstable shelf area of the Tethys

\footnotetext{
s1 See Note, p. iv.
}

Sea along the external rim of Taurides-Iranides has been the favored area of intensive and successful oil exploration. Much less exploration was carried out near the northern rim of the Nubo-Arabian Shield because the paleogeography and environment of deposition of the stable shelf area of the Tethys Sea had been considered unfavorable for forming commercial quantities of hydrocarbons. During more recent years, however, petroleum investigations in the Red Sea area, in Israel, and in Jordan have revealed that the stable shelf area of the Tethys Sea contains many more sedimentary basins and swells than had been expected. In some of these basins outside Jordan, oil and gas are now being commercially produced.

In Jordan, new geologic mapping of the entire country has permitted a reinterpretation of the geophysical, petroleum geological, and explorationdrilling results achieved during the periods 194749 (Transjordan Petroleum Development Co., Ltd.) ; 1956-60 (E. W. Pauley Oil Exploration and Phillips Petroleum Co., 6 exploration wells); 1964-66 (J. W. Mecom Oil Co., 3 exploration wells) ${ }^{32}$; and 196872 (Industrija Nafta Zagreb Yugoslavia, unpub. data, 1 exploration well). This reinterpretation (Bender, 1969) was substantially supported by recent geophysical and drilling activity for groundwater exploration by the UNFAO "Sandstone Aquifer Project in Southeast Jordan" in cooperation with Jordan's Natural Resources Authority (NRA), since 1964 (unpub. data, 1964-69; Lloyd, 1969; Parker, 1969), and by seismic investigations carried out for NRA by Arabian Geophysical and Surveying Co. (1968) ${ }^{33}$ in 1967-68.

It is thought accordingly that the Wādi al 'ArabahJordan Rift, as well as the northwest-striking basins of Al Jafr and Yarmūk-Al Azraq-Wādi as Sirb̧ān (pl. 3), represent zones of repeated structural subsidence and increased sediment accumulation, especially during the Maestrichtian-Danian-Paleogene. A north-northeast-striking sedimentary basin containing a considerably increased thickness of Triassic-Jurassic strata is in the area west of the Jordan River. Oil and (or) gas possibilities may exist in these sedimentary basins, in particular within the transition zones between the stable and the unstable shelf areas of the Tethys Sea. Such prospective areas for oil and (or) gas are:

1. Structural closures and stratigraphic traps in Cretaceous and older reservoir rocks overlying Cretaceous and possibly Jurassic-Triassic

\footnotetext{
${ }^{32}$ See footnotes 2-4 on p. I2.
} ${ }^{33}$ See footnote 27 on p. I21. 
source rocks in the Yarmūk-Al Azraq-Wādī Sirb̧ān Basin (total thickness above Precambrian approximately $5,000 \mathrm{~m}$, according to seismic investigations.)

2. Structural closures and stratigraphic traps in lower Tertiary and Cretaceous reservoir rocks below the thick Neogene evaporites or below and in the shale and marl facies equivalents of these evaporites, in the Al Lisan-Ghawr as Şāfi area, and in the central part of the Jordan Rift (total thickness of beds above Precambrian approximately $10,000 \mathrm{~m}$, on the basis of seismic investigations.)

3. Structural closures and stratigraphic traps in Lower Cretaceous, Jurassic, and Triassic reservoir rocks, especially those near the southern part of the Jordan-Dead Sea graben (total thickness of beds above Precambrian approximately $5,000 \mathrm{~m}$, on the basis of regional correlations.)

Bituminous rocks are found at different stratigraphic levels in several areas. The highest bitumen contents are in the Upper Cretaceous chalk-marl member (p. I20); the bituminous unit in this member is an euxinic facies deposited in sedimentary subbasins (fig. 17). In the Lajjūn area, Speers ${ }^{34}$ (1969) described a deposit of approximately 15 $\mathrm{km}^{2}$. The deposit is very uniform in character, and its average yield of shale oil by Fischer assay is 28.1 U.S. gal/ton. Reserves thus far established at Lajjūn are estimated to be about 420 million barrels of shale oil.

Asphalt has been found floating in the Dead Sea and has been collected in small quantities along its shores since ancient times. In 1939, a block of asphalt measuring $150 \mathrm{~m}^{3}$ was salvaged (Ionides and Blake, 1939, p. 122). The asphalt obviously is derived from faults exposed at the sea bottom. A fault breccia impregnated with asphaltic residual oil was observed southeast of Al Lisān Peninsula at the mouth of Wādi 'Isāl, where a north-northeaststriking major fault zone separates the echinoid limestone member (Cenomanian-Santonian) from Cambrian shale and sandstone. Because of the small quantities, the asphalt is of no commercial interest.

\section{METALLIC MINERALS} COPPER ${ }^{35}$

Copper mineralization is associated with several rock types on the east side of Wādi al 'Arabah be-

\footnotetext{
st Speers, G. C., 1969, El Lajjūn oil shale deposit, Jordan: Jordan Nat. Resources Authority and BP Research Center, unpub. rept., Jordan Nat. Res. Authority, Amman, Jordan.

ss See Note, p. iv.
}

tween Gharandal in the south and the Dead Sea in the north (Bender, 1965):

1. In Precambrian mafic dikes; traces, of no commercial interest.

2. In upper Proterozoic-Cambrian quartz porphyries; traces of oxidized disseminated copper ores deserve further investigations.

3. In the Lower Cambrian basal conglomerate; traces, of no commercial interest.

4. In the white fine-grained sandstone of latest Early to Middle Cambrian age.

5. In the dolomite time equivalents of the white fine-grained sandstone.

The mineralized sandstone and dolomite have some possibilities for economic utilization. In the sandstone, the mineralization consists of small ore nodules chiefly of malachite and, very subordinately (in the centers of nodules), of cuprite, chalcocite, bornite, and chalcopyrite. Locally, in the Wādi Abū Khushaybah area, as much as $6 \mathrm{~m}$ of the white fine-grained sandstone is mineralized, its copper content averaging 0.53 percent. In places where the mineralization is restricted to thicknesses of only $1.5 \mathrm{~m}$ to $0.2 \mathrm{~m}$ of the white fine-grained sandstone, the copper content of channel samples ranges from 1.0 to 9.8 percent.

North of Wādī Abū Khushaybah, some lateral equivalents of the white fine-grained sandstone are impure commonly sandy dolomites; the uppermost part of these dolomites is also mineralized, mainly with malachite along fissures and cracks (approximately 0.4 percent $\mathrm{Cu}$ over a 1.40 -m-thickness of dolomite). Furthermore, pockets of a few tons of high-grade copper ore are found at the top of the dolomites, and in some places the ore extends into the overlying sandstones. This ore consists of planchéite, malachite, and chrysocolla and contains a maximum of 47 percent $\mathrm{Cu}$. These ore pockets are irregular and are sparsely distributed in the dolomites.

The copper mineralization in the sandstone is thought to have been derived from contemporaneous quartz porphyry volcanism during the sandstone deposition (syngenetic), but the mineralization at the contact between dolomite and sandstone is explained by chemical precipitation from descending solutions containing some copper derived from stratigraphically higher sandstones (Bender, 1965).

\section{MANGANESE 80}

Manganese ore has been long known from the east side of the northern Wādi al 'Arabah, in the area of Wādī İānā. The ore, chiefly pyrolusite, subordin-

\footnotetext{
${ }^{30}$ See Note, p. iv.
} 


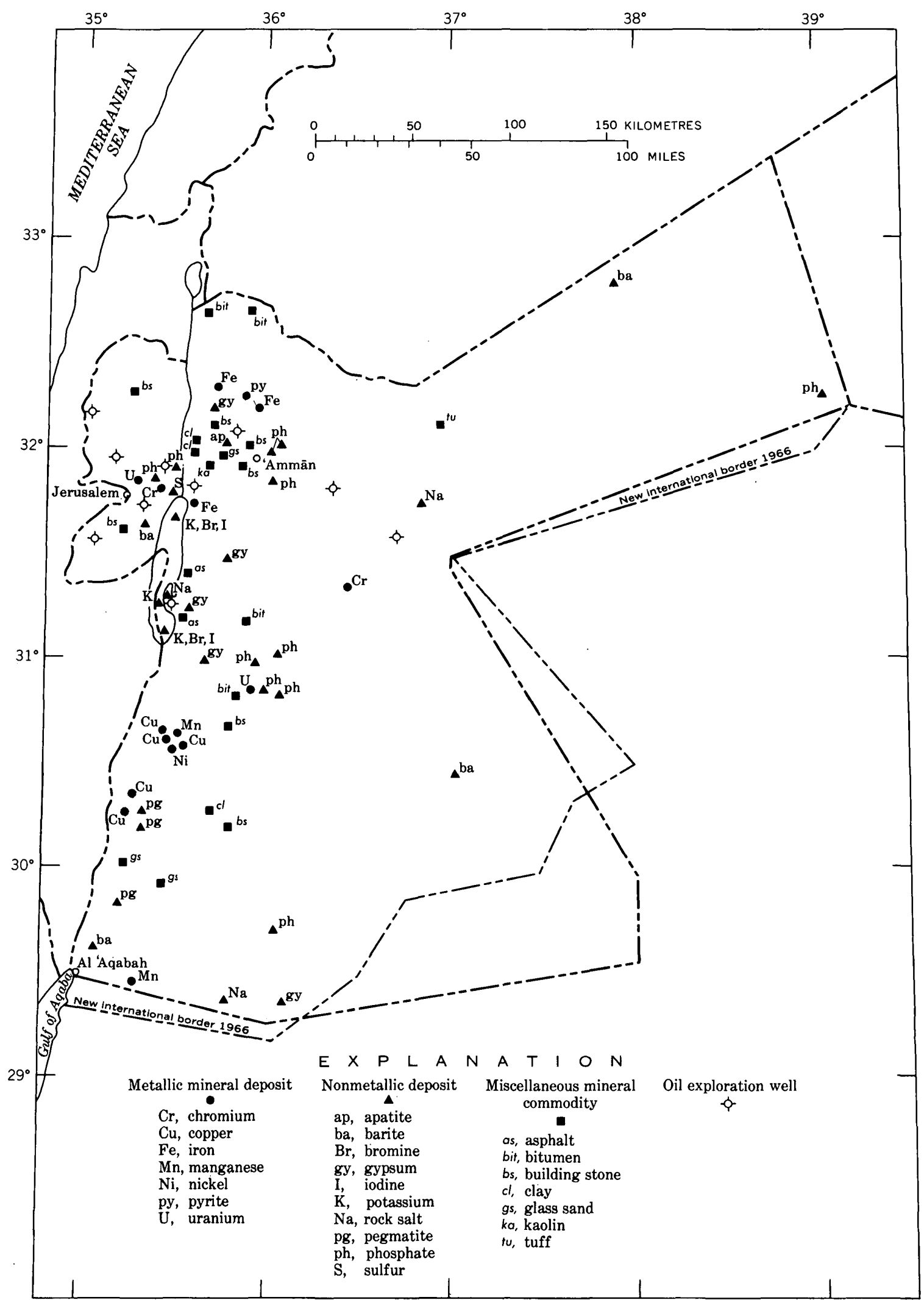

FIGURE 17.-Occurrences and indications of minerals and rocks of economic interest and locations of oil exploration wells in Jordan. (Modified from Bender, 1968a, with the kind permission of the publisher, Gebrüder Borntraeger, Stuttgart.) 
ately cryptomelane, ramsdellite, hematite, goethite, malachite, and azurite, consists of nodular masses as much as $3 \mathrm{~m}$ thick in the upper part of the dolomite-limestone-shale unit of latest Early to Middle Cambrian age. It is overlain by Cambrian sandstone. Toward the base of the ore zone, shale and sandy shale intercalations increase downward toward the barren part of the sequence. Laterally, the ore thickness may decrease within $200 \mathrm{~m}$, from $3 \mathrm{~m}$ to several centimeters thick, but may increase again at other localities; the ore is continuous for many square kilometers in the same stratigraphic interval. The metal content of 36 samples from different localities averaged 33.2 percent $\mathrm{Mn}$ and 1.7 percent $\mathrm{Cu}$ (Mackay \& Schnellmann, $1954{ }^{37}$ ). Van den Boom and Ibrahim (1954) ${ }^{38}$ mentioned the following metal contents: $\mathrm{Mn}$, between 36.3 and 49.4 percent; $\mathrm{Cu}$, between 1.11 and 2.06 percent; and $\mathrm{Fe}$, between 6.13 and 16.3 percent. According to van den Boom (1969), who gave a detailed description of the manganese ores of Wādi Dुānā, the deposit is of syngenetic origin.

Though 800,000 tons of ore reserves has been proven by exploration work done by the Jordan NRA, the economic feasibility of ore production will be uncertain until processing problems are solved.

\section{IRON}

Iron ore was mined in medieval times in the southern 'Ajlūn district, $7 \mathrm{~km}$ west of the village of Burmà (about $35 \mathrm{~km}$ north-northwest of 'Ammān).

The ore, dominantly hematite and some limonite, forms an irregular lenslike body of metasomatic origin within the massive limestone of CenomanianTuronian(?) age (lower part of the echinoid limestone member). Test drilling indicates that the ore body is about $300 \mathrm{~m}$ long and $200 \mathrm{~m}$ wide and has a maximum thickness of $9.80 \mathrm{~m}$. The average iron oxide content of 205 samples from 15 boreholes was 67.9 percent $\mathrm{Fe}_{2} \mathrm{O}_{3}$; the proven ore reserves are 561,000 tons (van den Boom and Lahloub, $1962{ }^{39}$ ).

\section{CHROMIUM, NICKEL, URANIUM, AND PYRITE}

Traces of chromium were described by Blanckenhorn $(1912,1914)$ from exposures along the Arihä (Jericho)-Jerusalem road and also east of the

\footnotetext{
I7 See footnote 5 on p. I2.

ss Boom, Günter van den, and Ibrahim. H., 1965, Report on the geology of the Waidi Dana area, with special consideration of the manganese-copper occurrences: German Geol. Mission in Jordan, unpub. rept. Fed. Rep. Germany Geol. Survey, Hannover, 93 p. ${ }^{30}$ See footnote 22 on $p$. I18.
}

Jordan River at some localities in the chalk-marl member of late Maestrichtian-early Eocene age (p. I20). Eckhardt and Heimbach (1963) identified a hitherto unknown chromium mineral, chromatite $\left(\mathrm{CaCrO}_{4}\right)$, from these outcrops. The chromium is of no economic interest.

Traces of nickel are associated with Precambrian copper-bearing mafic dikes $(0.001-0.01$ percent $\mathrm{Ni})$, with the copper mineralization of Cambrian sandstones and dolomites $(0.001-0.01$ percent $\mathrm{Ni})$, with the manganese ores of Wādi Dुānā (0.01-0.1 percent $\mathrm{Ni}$ ), and with the greenish porphyrite complex east of Faynān (Feinān) at the east side of the northern Wãdī al 'Arabah (Bender, 1968a, p. 152). The greenish material of a porphyrite sample contained 0.7 percent $\mathrm{Ni}$.

Several uranium minerals have been found in the phosphorite member and in the overlying chalkmarl member (Maestrichtian-lower Eocene), from exposures in many parts of Jordan; uranophane, tuyamunite, and metatuyamunite were identified by F. J. Eckhardt, Geological Survey, Federal Republic Germany (written commun., 1962). The phosphate rock produced in the Ar Ruşayfah and in the Mahattat al Hुasā areas contains an average of 100 to $125 \mathrm{ppm} \mathrm{U}_{2} \mathrm{O}_{3}$, which corresponds to the world wide average of $\mathrm{U}_{2} \mathrm{O}_{3}$ content in phosphates $(\mathrm{H}$. Fauth, Geological Survey, Federal Republic Germany, written commun., 1969).

Pyrite is locally abundant in dark shales in the uppermost Lower Cretaceous sequence, approximately 20 to $30 \mathrm{~m}$ below the base of the Cenomanian nodular limestone member. No pyrite of economic value is known.

\section{NONMETALLIC MINERALS ${ }^{40}$ PHOSPHATE}

Geologic mapping $(1: 25,000$ scale) of all the phosphate-prospective areas in Jordan was done during 1961-66 by the German geological mission. The phosphorite member (pl. 2; fig. 18) could be traced approximately $250 \mathrm{~km}$ from the area of Ra's an Naqb in south Jordan to the area north of 'Ammann, and the stratigraphic correlation as well as the structural pattern of the "phosphate belt" was established.

Phosphate deposits of economic interest in Jordan are in the Maestrichtian rock sequence between Maḩațat al Hुasā in the south and Şuwaylih northwest of 'Ammann. Here, the Upper Cretaceous formations, which generally have a phosphate content too low to be of commercial value, locally contain lens- 


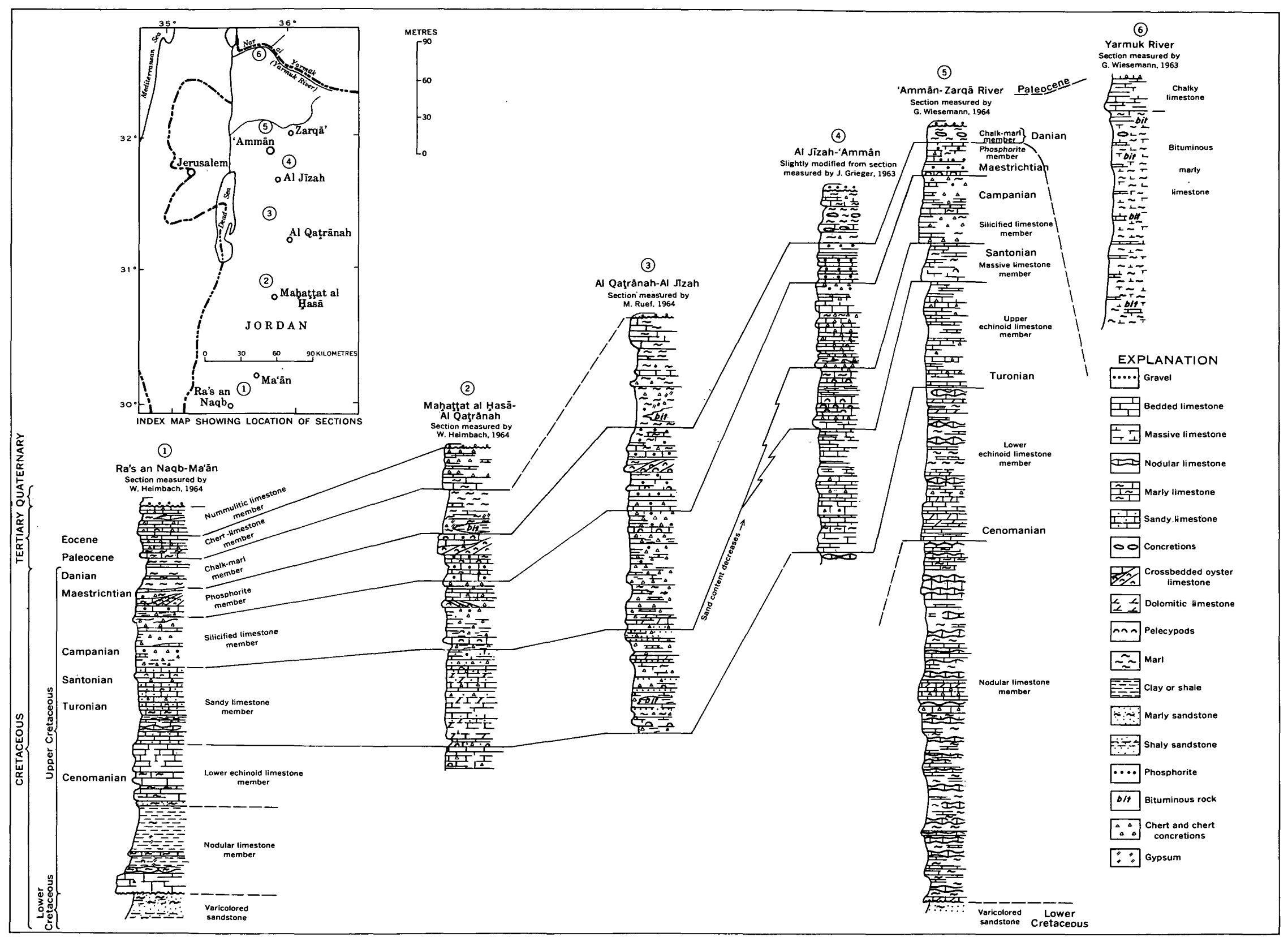

FIGURE 18.-North-south correlation of Upper Cretaceous-lower Tertiary lithostratigraphic units. (Slightly modified from Bender, 1968a, with the kind permission of the publisher, Gebrüder Borntraeger, Stuttgart.) 
like ore bodies or seams of considerable extent and thickness. Because of the regional slight dip of the phosphorite member to the east and the consequent thickening of overburden toward the east, the eastern boundary of the phosphate belt has not yet been defined. Its western border, however, was traced accurately in surface mapping, because the phosphatebearing strata are uplifted in the west along the mountain ridge east of the rift valley.

In the individual prospective areas (fig. 17), the following observations were made:

1. In southeast Jordan, for example in the area of the village of Hattiya, in the area of $\mathrm{Al}$ 'Ināb and northeast and east of the ruins of Kilwah, phosphorite facies are found in Turonian to Danian-Paleocene-E oc en e (?) rocks. The phosphorite facies diachronously "migrates" into successively younger stratigraphic levels from west to east. All phosphate concentrations known in this area are less than $1 \mathrm{~m}$ thick and are mostly silicified, calcified, or sandy. No deposit of economic value has yet been discovered in southeast Jordan.

2. In south Jordan (Ra's an Naqb-Ma'ān), some phosphorite occurs in the upper part of the sandy limestone member and in the silicified limestone member (Turonian-Santonian-Campanian; pl. 2). The main phosphorite occurrence, however, is restricted to the phosphorite member (lower Maestrichtian) which is approximately $20 \mathrm{~m}$ thick in this area. Quality and quantity of the phosphate ores are below the margin for commercial production in this part of south Jordan.

3. In the Mahatțat al Hasā-Al Qațrānah area, the phosphorite member (Maestrichtian) increases in thickness to about $40 \mathrm{~m}$. Mostly in its lower third, but also in its upper part, several phosphate-rich layers and lenses are separated from each other by limestone, marl, and chert. Locally the high-grade ore lenses are as much as $10 \mathrm{~m}$ thick (fig. 19). The minable phosphorite in the individual lenses ranges from 1 million to 15 million tons. So far, approximately 53 million tons of ore containing more than 67 percent tricalcium phosphate has been proven in this area.

4. Between Al Qațānah and 'Ammān, other promising phosphorite layers were located during geologic mapping, but as yet have not been prospected sufficiently to justify reserve calculations.

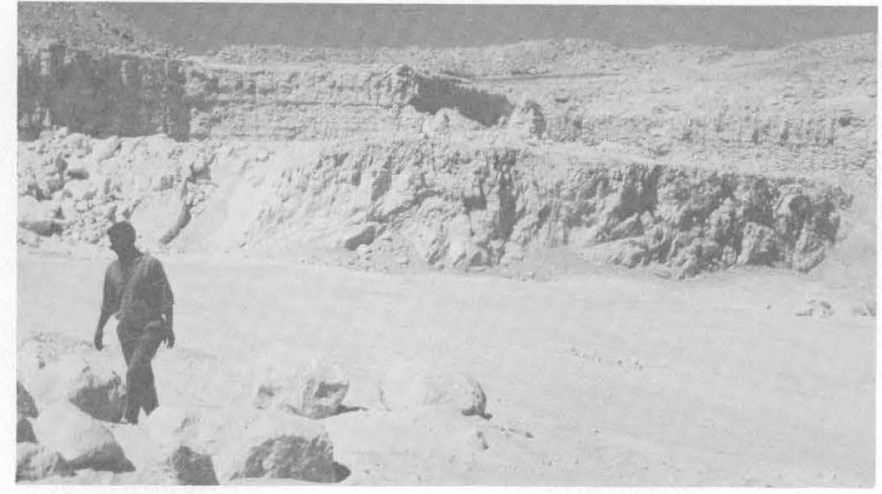

Frgure 19.-Phosphate in open-pit mine at Mahatţat al Ḩasā; ore body of Old Concession in central part of photograph approximately $5 \mathrm{~m}$ thick.

5. Approximately $15 \mathrm{~km}$ northeast of 'Ammān are the well-known and commercially productive phosphate deposits of Ar Ruşayfah. The four layers that are mined are more constant in thickness than are the ore-bearing layers farther south. At Ar Rusayfah, the ore-bearing phosphorite member is about $30 \mathrm{~m}$ thick and is of Maestrichtian Age. About 39 million tons of phosphate ore containing more than 62 percent tricalcium phosphate have been proved in the Ar Ruşayfah area.

6. North of Ar Ruşayfah-'Ammān, no phosphate deposits of economic value are known.

7. In the area west if the Jordan River the phosphorite meinber is $25-35 \mathrm{~m}$ thick, but the phosphate beds are very impure and thin. The phosphorite member in this area is probably of Campanian Age.

8. In northeast Jordan, impure and thin phosphorite layers were discovered in the lower Tertiary, about $70 \mathrm{~km}$ south of the Baghdad road, close to the Jordan-Iraq border (fig. 17). These phosphorites have not yet been investigated in detail.

\section{OTHER MINERALS ${ }^{41}$}

About $16 \mathrm{~km}$ northwest of 'Ammān, the phosphorite member crops out in a steep, partly overturned flexure. Here, most of the phosphorite is altered to hard, dense, gray-greenish and red apatite. The reserves of apatite ore are estimated to be 900,000 tons. The average tricalcium phosphate content is about 70 percent. The results of a detailed geologic study of this the only apatite deposit in Jordan, have been published by Wiesemann and Rösch (1969). 
Barite is present $10 \mathrm{~km}$ east-southeast of Bayt Sāhūr (west of the Jordan River) as an irregular mass in limestone and marl of Turonian(?)-Santonian Age. It also fills dikes as much as $0.60 \mathrm{~m}$ thick in the lower Eocene calcareous beds of northeast Jordan, $46 \mathrm{~km}$ northwest of oil pumping station $\mathrm{H}-4$. Other thin barite dikes were found in major fault zones on the east side of southern and central Wādi al 'Arabah. In the crest of an anticlinal structure at Zakimat al Hुasā, $52 \mathrm{~km}$ southeast of Bāyir, barite rosettes were observed in the varicolored sandstone of Early Cretaceous-Cenomanian Age. Commercial production on a small scale may be possible from the irregular mass near Bayt Sāhūr and from the dikes in northeast Jordan.

Feldspar and mica are common in the Precambrian igneous rock complex, but their quality and quantity do not justify production. Orthoclase or potassium feldspar might eventually be produced by processing the pegmatitic granites near $\mathrm{Al}$ Quwayrah.

Quartz forms the main constituent of many pegmatite dikes in the igneous basement complex, in particular along the east side of central and southern Wādì al 'Arabah. In most places, however, the quartz is too impure and disseminated for any commercial use.

Glass sands of good quality and of practically unlimited quantity have been observed in the lower part of the Lower Cretaceous massive white sandstone unit, and in the massive whitish-weathered sandstone unit of Early Ordovician age. Suitable exposures for glass sand production from both of these stratigraphic units are in the area of Qā 'Disah in southern Jordan, at several places along the highway crossing the escarpment of Ra's an $\mathrm{Naqb}$, in the Wādi as Sìq approximately $7 \mathrm{~km}$ eastsoutheast of Gharandal, and near the road between Nā'ūr and Ash Shāgūr.

Agate and rock crystals (quartz) are occasionally found in vugs, concretions, and fillings of joints in the silicified limestone member (Campanian), and in the chert-limestone member (lower Eocene)for example, along the outcrop belt of these rocks between Ra's an Naqb and Al Quatrānah, near Mahaţ̧at Baţn al Ghūl, and approximately $20 \mathrm{~km}$ southeast of Bi'r an Na'ām in southeast Jordan. These occurrences are of no economic importance.

Garnet was discovered in gravels and sands of the Wādì Abū Barqā and Wādì Hūwar $(7 \mathrm{~km}$ and 17.5 $\mathrm{km}$ north-northeast of Gharandal on the east side of the Wādi al 'Arabah), and in biotite-garnet schists exposed along the middle course of Wādi
Abū Barqā, as well as at the part of Wādì Hūwar south of Jabal al Muraybid. Because of the impure quality of the garnets and because of the small quantities so far located, they can hardly be considered as having any commercial value.

Semiprecious stones such as malachite, chrysocolla, and plancheite, are constituents of the epigenetic copper ores in the Cambrian dolomitesandstone complex (p. I27), in the area of Faynān on the east side of the northern Wādi al 'Arabah. Cutting and polishing tests have shown that these minerals are suitable for gem-stone manufacture. Pockets and lenses of as much as 1 ton of malachite, chrysocolla, and planchéite were found during geologic mapping (Bender, 1965, p. 196).

Gypsum forms beds 1-4 $\mathrm{m}$ thick in the middle part of the Cenomanian nodular limestone member in the Wãdi al Karak, and in the lower third of the echinoid limestone member (Cenomanian-Turonian) at the northern slope of Wādi al Mawjib. Gypsum is also exposed about $35 \mathrm{~km}$ northwest of 'Ammān, at the mouth of Wādī al Hūnah into the Nahr az Zarqa' River, in a 25 -m-thick part of the Triassic rock sequence. These occurrences could be eventually of commercial value, but thin gypsum layers in the chalk-marl member (Maestrichtian-Danian), and gypsum lamina and gypsum concretions in the Lisan Formation are of no economic interest.

Several layers of anhydrite were penetrated in the wildcat oil wells SAFRA-1 (E. W. Pauley Oil Exploration and Phillips Petroleum Co., 1957 ${ }^{42}$ ) in Lower Cretaceous (?), Jurassic, and Triassic rocks; anhydrite was also in the Miocene(?)-Pliocene evaporite sequence in El Lisan-1 (E. W. Pauley Oil Exploration and Phillips Petroleum Co., $1960^{42}$ ), and in other wells on the Al Lisān Peninsula in the Dead Sea (Jordan Natural Resources Authority, unpub. data, 1967, 1968).

Rock salt is produced in small quantities in the area of the Al Azraq Basin, where saline ground water is collected in trenches and brought into evaporation pans.

The almost unlimited reserves of rock salt that underlie about $100 \mathrm{~m}$ of upper Pleistocene marls on the Al Lisān Peninsula in the Dead Sea have not been utilized as yet.

The amount of rock salt dissolved in the Dead Sea is estimated to be approximately 12,650 million tons. Because of impurities, in particular the magnesium salts, rock salt cannot be produced by simple evaporation of the sea water.

\footnotetext{
42 See footnote 3 on p. I2.
} 
Potash and magnesium salts are also dissolved in huge quantities in the Dead Sea water. The total amount of dissolved $\mathrm{KCl}$ is calculated to be about 2 billion tons, and the amount of $\mathrm{MgCl}_{2}$ is about 23 billion tons (Bentor, 1961). In the total water volume $\left(143 \mathrm{~km}^{3}\right)$ of the Dead Sea, the dissolved bromine salts amount to 975 million tons $\mathrm{MgBr}_{2}$ and the rubidium salts amount to 12 million tons $\mathrm{RbCl}$ (Bentor, 1961).

Potash layers were first discovered in the $\mathrm{El}$ Lisan NRA-1 well (Jordan NRA, unpub. data, 1967), which penetrated a part of the Miocene(?)Pliocene evaporite sequence at the southeast side of the Al Lisān Peninsula (Bender, 1969, p. 602). Little is yet known about the extent of these potash layers.

Native sulfur is widespread in the upper Pleistocene Lisan Formation; the formation can be traced in the rift valley from the north shore of the Dead Sea for more than $40 \mathrm{~km}$ to the north. The sulfur occurs as finely crystalline coatings on joints and fault planes, along bedding planes, and in small pockets within gypsum concretions. Paper-thin layers of amorphous sulfur are locally interbedded with the alternating, varvelike shales and marls. Variable quantities of amorphous sulfur nodules 0.5$10 \mathrm{~cm}$ in diameter cover the bedding planes in parts of the Lisan Formation. The distribution of sulfur is very irregular, and no place has yet been discovered where commercial sulfur production from the Lisan Formation would be justified.

Ochre and umber occur at several places within sandy gypsiferous lacustrine sediments of middle (?) Pleistocene age on the plateau of Lower Cretaceous sandstones at HJumrat Mā'īn, north of Wādì Zarqā' Mā'ayn. These raw materials for pigment consist of small irregular lenses as much as $1 \mathrm{~m}$ thick of yellow ochre and of dark-brown to black, impure, earthy manganese ore containing gypsum. It is not known whether these pigments are suitable for commercial use.

Clay deposits of commercial value crop out locally in northern Jordan within the massive white sandstone unit of Early Cretaceous age. At Ghawr Kabid on the east side of the Jordan River valley, a clay bed 0.40-6.0 $\mathrm{m}$ thick is exposed which has an aluminum content of 32.8-37.6 percent; the proven reserves are 47,000 tons. In the area of Mābiș, a similar deposit of about 46,000 tons of clay is exposed.

Substantial parts of the nodular limestone member (Cenomanian) meet the requirements of raw material for cement (25-60 percent carbonates, 4075 percent noncarbonates). Portland cement is be- ing produced from this rock unit near Al Fuhayș, north of 'Ammān.

Tuff is found in volcanic cones and as thin sheets in the basalt area in northeast Jordan. It has been produced for many years from Jabal ar Rutayn east of Al Mafraq, mainly for lightweight concrete, for thermal-insulation material, and for roadmaking material. The tuff reserves are sufficient for commercial production at a much bigger scale than at present.

Only a few examples of the multitude of building stones used since ancient times in Jordan will be mentioned here:

1. Oolitic limestone of Pleistocene age exposed in the western Jordan River, near Kirbat as Samrā'.

2. Thick and hard caliche (referred to as "Nari" in Jordan) of Quaternary age, in the area of Jarash.

3. Massive oyster-shell limestones of the phosphorite member of Campanian-Maestrichtian Age, in the area between 'Ammān and $\mathrm{Al}$ Qatrānah.

4. Greenish, reddish, light-pink, and white limestones of different units of Turonian to Maestrichtian Age west of the Jordan River, particularly in the vicinity of Jerusalem and Bethlehem.

5. Reddish, pink, beige, and light-gray limestones in the upper part of the echinoid limestone member and in the massive limestone member of Turonian-Santonian Age, which are extensively quarried in and near 'Ammān and at many other localities in north Jordan.

Well qualified as decoration stones are hornblende gabbro, quartz diorite, granodiorite, and, locally, quartz porphyry, as exposed at many places on the east side of Wādi al 'Arabah and in the area of $\mathrm{Al}$ Quwayrah in southern Jordan.

The rocks quarried and sold as marble in Jordan are actually polishable limestones. They are only slightly recrystallized, hard and dense, and are heavily jointed and fissured. These limestones are variously colored by iron compounds, bituminous matter, apatite and traces of chromium-, nickel-, vanadium-, and uranium-bearing minerals. The limestones are present locally in the upper part of the chalk-marl member of latest Cretaceous to early Tertiary age, and are extensively quarried east and west of the desert highway between Al Jizah and Al Qaţrānah, particularly in the area of Qasr el Ḩammām.

The lower Pleistocene travertine of the Shagur 
Formation can be considered as a valuable building and decoration stone, which so far has not been utilized in Jordan. At several places along the east side of the Jordan River valley the travertine is suitable for quarrying. Approximately $10 \mathrm{~km}$ south of Dayr 'Allā, extensive outcrops almost parallelbedded travertines as much as $10 \mathrm{~m}$ thick were observed.

\section{SELECTED REFERENCES}

Auler, Pascha, 1908, Die Hedschasbahn. II. Teil: Ma'an bis el-Ula: Petermanns Geog. Mitt., Ergänzungsh. 1617.

Avnimelech, Moshé, 1945, A new Jurassic outcrop in the Jordan Valley: Geol. Mag., v. 82, no. 2, p. 81-83.

Bender, Friedrich, 1965, Zur Geologie der Kupfererzvorkommen am Ostrand des Wadi Araba, Jordanien: Geol. Jahrb., v. 83, p. 181-201.

- 1968a, Geologie von Jordanien: Beitr. regionalen Geologie Erde, v. 7, 230 p.; Berlin, Gebrüder Borntraeger.

1968b, Über das Alter und die Entstehungsgeschichte des Jordangrabens am Beispiel seines Südabschnittes (Wadi Araba, Jordanien) : Geol. Jahrb., v. 86, p. 177196.

1969, Ergebnisse erdölgeologischer Untersuchungen in Jordanien: Erdöl u. Kohle, v. 22, no. 9, p. 510-515; no. 10, p. 597-604.

Bender, Friedrich, and Huckriede, Reinhold, 1963, Stratigraphie der "Nubischen Sandsteine" in Südjordanien: Geol. Jahrb., v. 81, p. 237-276.

Bender, Friedrich, and Mädler, Karl, 1969, Die sandige Schichtenfolge der Kreide mit einer Angiospermen-Flora in Südjordanien: Geol. Jahrb., Beihefte, no. 81, p. 35-92.

Bender, Friedrich, Boom, G. van den, Busse, R., Futian, A., Grieger, J., Haddadin, M., Heimbach, W., Ibrahim, H., Jerasat, K., Khdeir, K., Lahloub, M., Lenz, R., Lillich, W., Ruef, M., Sunna, B., and Wiesemann, G., 1968, Geologische Karte von Jordanien: Hannover, Germany, Bundesanst. Bodenforschung, 5 sheets (Amman, El Azraq, Mahattat el Jufur (H-4), Aqaba-Ma'an, Bayir), scale $1: 250,000$

Bentor, Y. K., 1961, Some geochemical aspects of the Dead Sea and the question of its age: Geochim. et Cosmochim. Acta, v. 25, no. 4, p. 239-260.

Bertou, M. de, 1839, Itinéraire de la Mer Morte, par le Ghor à Akaba, et retour à Hebron: Soc. Geog. France Bull. 11.

Blake, G. S., 1928, Geology and water resources of Palestine: Palestine Geol. Adviser Pub. 1, 51 p.

1930, The mineral resources of Palestine and Transjordan: Palestine Geol. Adviser Pub. 2, 41 p.

1936, The stratigraphy of Palestine and its building stones: Jerusalem, Printing and Stationary Office, 133 p. - 1939, Geological map of Palestine: Jerusalem, Survey of Palestine, scale 1:250,000.

Blake, G. S., and Goldschmidt, M. J., 1947, Geology and water resources of Palestine: Jerusalem, Palestine Dept. Land Settlement and Water Commissioner, $481 \mathrm{p}$.

Blanckenhorn, Max, 1903, Die Mineralschätze Palästinas: Deutsch.-Paläst. Ver., Mitt. und Nachr., 1902, p. 65-70.
1912, Naturwissenschaftliche Studien am Toten Meer und im Jordantal: Berlin, Friedländer, $478 \mathrm{p}$.

1914, Syrien, Arabien und Mesopotamien: Handbuch der regionalen Geologie, v. 5, no. 4, 159 p. (Heidelberg).

Boom, Günter van den, 1969, Zur Geologie und Genese der Manganerz-Vorkommen im Wadi Dana: Geol. Jahrb., Beihefte, no. 81, p. 161-176.

Boom, Günter van den, and Rösch, Heinrich, 1969, Modalbestand und Petrochemie der Granite im Gebiet von Aqaba-Quweira, Südjordanien: Geol. Jahrb., Beihefte, no. 81, p. 113-143.

Bramkamp, R. A., Brown, G. F., Holm, D. A., and Layne, N. M., Jr., 1963, Geologic map of the Wadi As Sirhan quadrangle, Kingdom of Saudi Arabia: U.S. Geol. Survey Misc. Geol. Inv. Map I-200A, scale 1:500,000.

Burdon, D. J., 1959, Handbook of the geology of Jordan: [Amman], Jordan, Hashemite Kingdom, 82 p.

Cox, L. R., 1924, A Triassic fauna from the Jordan Valley: Annals and Mag. Nat. History, ser. 9, v. 14, p. 52-96. 1925, A Bajocian-Bathonian outcrop in the Jordan Valley and its molluscan remains: Annals and Mag. Nat. History, ser. 9 , v. 15 , p. $169-181$.

1932, Further notes on the Transjordan Triassic: Annals and Mag. Nat. History, ser. 10, v. 10, p. 93-113. 1934, On the occurrence of the marine Oligocene in Palestine: Geol. Mag., v. 71 , no. 842 , p. $337-355$.

Dienemann, W., 1915, Älteres Paläozoikum von Südsyrien und Westarabien: Centralblatt Mineralogie, Geologie, Paläontologie, v. 16, p. 23-26.

Dubertret, Louis, 1932, Les formes structurales de la Syrie et de la Palestine; leur origine: Acad Sci. Comptes Rendus, v. 195, p. $65-67$.

1959, Carte géologique internationale de l'Afrique Feuille 3: Paris, Impr. Michard, scale 1:5,000,000.

1962, Carte géologique Liban, Syrie et bordure des pays voisins: Paris, Mus. Nat'l. d'Histoire Nat.

Eckhardt, F. J., and Heimbach, Wolfgang, 1963, Ein natürliches Vorkommen von $\mathrm{CaCrO}$ (Chromatit): Naturwissenschaften, v. 50 , no. 19 , p. 612 .

Edwards, W. N., 1929, Lower Cretaceous plants from Syria and Transjordan: Annals and Mag. Nat. History, v. 10, no. 4 , p. $394-405$.

Fraas, Oskar, 1867a, Aus dem Orient, I. Teil: Geologische Beobachtungen am Nil, auf der Sinai Halbinsel und in Syrien: Stuttgart, Elbner \& Senbert, 23 p.

1867b, Das Tote Meer: Stuttgart.

Freund, Raphael, 1965, A model of the structural development of Israel and adjacent areas since Upper Cretaceous times: Geol. Mag., v. 102, no. 3, p. 189-205.

Fuchs, Ernst, 1916, Beiträge zur Petrographie Palästinas und der Hedschasprovinz: Neues Jahrb. Mineralogie, Geologie u. Paläontologie, Suppl. v. 40, p. 533-582.

Gerry, E., 1967, Paleozoic and Triassic Ostracoda from outcrops and wells in southern Israel: Israel Inst. Petroleum, Joint Paleontol. Lab. Rept. 9 p.

Heimbach, Wolfgang, 1970, Zur Geologie Nordost-Jordaniens: Geol. Jahrb., v. 88, p. 265-288.

Helal, A. H., 1965, On the occurrence and stratigraphic positions of Permo-Carboniferous tillites in Saudi Arabia: Geol. Rundschau, v. 54 (1964), no. 1, p. 193-207.

Hennig, Edwin, 1938, Die alten Kerne; Abschnitt V, Afrika (ohne Atlasländer und Madagaskar) nebst Arabien: 
Regional Geologie der Erde, v. 1, 154' p. (Leipzig, Akadem. Verlag.)

Huckriede, Reinhold, 1966, Das Quartär des arabischen Jordan-Tales und Beobachtungen über "Pebble Culture" und "Prä-Aurignac": Eiszeitalter u. Gegenwart, v. 17, p. 211-212.

1967, Archaeonectris benderi n. gen. n. sp. (Hydrozoa), eine Chondrophore von der Wende Ordovicium/ Silurium aus Jordanien: Geologica et Palaeontologica, v. 1, p. 101-106.

Hull, Edward, 1886, Memoir on the physical geology and geography of Arabia Petraea, Palestine, and adjoining districts, with special reference to the mode of formation of the Jordan-Arabah depression and the Dead Sea: Adelphi, Survey of Western Palestine, 145 p. (London, R. Bentley \& Sons)

Ionides, M. G. and Blake, G. S., 1939, Report on the water resources of Transjordan and their development; incorporating a report on geology, soils, and minerals and hydrogeological correlations, by G. S. Blake: Government of Transjordan, $372 \mathrm{p}$.

King, W. B. R., 1923, Cambrian fossils from the Dead Sea: Geol. Mag., v. 60, p. 507-514.

Kober, Leopold, 1919, Geologische Forschungen in Vorderasien, II., Teil C. Das nördliche Hegâz: Akad. Wiss. Wien Denkschr. 96, p. 779-820.

Krenkel, Erich, 1924, Der Syrische Bogen: Centralbl. Mineralogie, Geologie, Paläontologie, Abt. B., v. 9 and 10, p. 274-281, 301-313.

1925, Geologie Afrikas: Berlin, Gebrüder Borntraeger, v. 1, 461 p.

1941, Syrarabien: Z. deutsch. Geol. Ges., v. 93, p. 357-376.

Krusch, P., 1911, Die Phosphatlagerstätte bei Es-Salt im Ostjordanland: Zeitsch. Prakt. Geologie, v. 19, 347-406.

Kruse, Fr., 1854-1855 (herausgeg. u. kommentiert) Ulrich Jasper Seetzen's Reisen durch Syrien, Palästina, Phönicien, die Transjordan-Länder, Arabia Petraea und Unterägypten: Berlin, Reimer, 3 v.

Lartet, L. M. H., 1869, Essai sur la géologie de la Palestine: Annales Sci. Géol., v. 1, p. 1-116, 149-329.

1876, Exploration géologique de la Mer Morte, de la Palestine et de l'Idumée: Paris, A. Betrand, $326 \mathrm{p}$.

Lenz, H., Bender, F., Besang, C., Harre, W., Kreuzer, H., Müller, P., and Wendt, J., 1972, The age of early tectonic events in the zone of the Jordan geosuture, based on radiometric data: Internat. Geol. Cong. 24th sess., sec. 3, p. 371-379.

Lillich, Wolfgang, 1969, Sedimentologische Untersuchungen in kambrischen Sandsteinen Jordaniens: Geol. Jahrb. Beihefte, no. 81, p. 13-34.

Lloyd, J. W., 1969, The hydrogeology of the southern desert of Jordan: UN Devel. Programme/Food and Agriculture Organization Proj. UNDP/FAO 212, Tech. Rept. no. 1.

Lynch, W. F., 1852, Official report of the United States expedition to explore the Dead Sea and the River Jordan: Baltimore, John Murphy \& Co., 235 p.

Milne, John, 1875, Geological notes on the Sinaitic Peninsula and northwestern Arabia: Geol. Soc. London Quart. Jour., v. 31, p. 1-28.
Muir-Wood, H. M., 1925, Jurassic Brachiopoda from the Jordan Valley: Annals and Mag. Nat. History, ser. 9, v. 15, p. 181-192.

Musil, Alois, 1907, Arabia Peträa: Vienna, A. Hölder, 3 v. in 4.

1911, Im nördlichen Hegaz. Vorbericht über die Forschungsreise 1910: Akad. Wiss. Wien Philos. hist. Kl., Anzeigen, v. 8.

Parker, D. H., 1969, The hydrogeology of the MesozoicCainozoic aquifers of the western highlands and plateau of east Jordan: UN Devel. Programme/Food and Agriculture Organization Proj. UNDP/FAO 212, Tech، Rept. $2,4 \mathrm{v}$.

Picard, Leo, 1928, Zur Geologie der Kischon-Ebene: Deutsch. Palästina Ver. Zeit., v. 51, p. 5-27.

- 1931, Geological researches in the Judean desert: Jerusalem, Goldberg's Press, 108 p.

1941, The Precambrian of the north Arabian-Nubian massif: Hebrew Univ., Jerusalem, Geol. Dept. Bull., v. 3 , no. $3-4,30$ p.

1942, New Cambrian fossils and Paleozoic problematica from the Dead Sea and Arabia: Hebrew Univ., Jerusalem, Geol. Dept. Bull., v. 4, no. 1, 18 p.

1943, Structure and evolution of Palestine: Hebrew Univ., Jerusalem, Geol. Dept. Bull., v. 4, no. 2-4, 135 p. 1953, Silurian in the Negev (Israel): Internat. Geol. Cong., 19th, Algiers, 1952, Comptes rendus, sec. 2, no. 2, p. 179-183.

1965, The geological evolution of the Quaternary in the central-northern Jordan graben, Israel: Geol. Soc. America Spec. Paper 84, p. 337-366.

Quennell, A. M., 1951, The geology and mineral resources of (former) Transjordan: Colonial Geology and Mineral Resources, v. 2, no. 2, p. 85-115.

- 1956, Geological map of Jordan (east of the Rift Valley) : Jordan Dept. Lands and Surveys, 3 sheets (Amman, Karak, Ma'an), scale 1:250,000.

Rath, G. vom, 1881, Palästina und Libanon-Geologische Reiseskizze: Niederrhein. Gesell. Natur- u. Heilkunde, Bonn, Sitzungsber., v. 38, no. 4, p. 66-114.

Richter, Rudolf, and Richter, Emma, 1941, Das Kambrium am Toten Meer und die älteste Tethys: Senckenberg. Naturf. Gesell. Abh., 460, 50 p.

Ritter, Carl, 1848-55, Vergleichende Erdkunde der Sinai Halbinsel, von Palästina und Syrien: Berlin, G. Reimer, 4 v.

Russegger, Joseph, 1847, Reisen in Europa, Asien und Afrika, v. 3, Reisen in Unter-Ägypten, auf der Halbinsel des Sinai und im gelobten Lande: Stuttgart, Schweizerbart.

Schubert, G. H. von, 1837, Reise in das Morgenland in den Jahren 1836 und 1837: Erlangen, Germany, J. J. Palm und E. Emke, [3 v.].

Schwöbel, V., 1921, Der Jordangraben, in Hettner Festschrift "Zwölf länderkundliche Studien": Breslau, p. 117-188.

Seetzen, U. J., 1810, Brief account of the countries adjoining the Lake of Tiberias, the Jordan, and the Dead Sea: London, Bath, Meyler \& Son, 61 p. (see Kruse, 18541855).

Shaw, S. H., 1947, Southern Palestine geological map on a scale of 1:250,000 with explanatory notes: Jerusalem, Palestine Geol. Sec., Pub. Works Dept., 42 p. 1948, The geology and mineral resources of Palestine: London, Imp. Inst. Bull. 46, p. 87-103. 
Sitter, L. U. de, 1962, Structural development of the Arabian shield in Palestine: Geologie Mijnbouw, v. 41, no. 3, p. 116-124.

U.S. Geological Survey and Arabian-American Oil Company (Aramco), compilers, 1963, Geologic map of the Arabian Peninsula: U.S. Geol. Survey Misc. Geol. Inv. Map I-270A, scale 1:2,000,000.

Vita-Finzi, Claudio, 1964, Observations on the late Quaternary of Jordan: Palestine Exploration Quart. (London) p. 19-33.

Vries, H. L. de, and Barendsen, G. W., 1954, Measurements of age by the carbon-14 technique: Nature, v. 174 , no. 4442 , p. 1138-1141.

Wagner, Georg, 1934, Deutscher Muschelkalk ("Wellengebirge") am Toten Meer: Natur und Volk, v. 64, no. 11, p. $449-454$.

Weber, Hans, 1963, Ergebnisse erdölgeologischer Aufschlussarbeiten der DEA in Nordost-Syrien: Erdöl u. Kohle, v. 16, p. $669-682$.
Wetzel, René, and Morton, D. M., 1959, Contribution à la géologie de la Transjordanie: Notes et Mém. MoyenOrient, v. 7, p. 95-191.

Wiesemann, Gerd, and Rösch, Heinrich, 1969, Das ApatitVorkommen von Suweilih bei Amman (Nord Jordanien): Geol. Jahrb., Beihefte, no. 81, p. 177-214.

Willis, Bailey, 1928, Dead Sea problem-Rift valley or ramp valley [abs.]: Geol. Soc. America Bull., v. 39, p. 152153.

1938, Wellings' observations of Dead Sea structure (with discussion): Geol. Soc. America Bull., v. 49, no. 4, p. $659-668$.

Wilson, G. R., and Wozab, D. H., 1954, Chemical quality of waters occurring in the Jordan Valley area: Assoc. Int. Hydrol. Sci., Assemblée gén., Rome, 1954, v. 2 (Pub. 37), p. 170-178.

Wolfart, Reinhard, 1968, Stratigraphie und Fauna des OberOrdoviziums (Caradoc-Ashgill) und Unter-Silurs (UnterLlandovery) von Südjordanien: Geol. Jahrb., v. 85, p. 517-551.

מU.S. GOVERNMENT PRINTING OFFICE: 1975 0-585-4/76/7 